\title{
Perspectives of Lipid Extraction By Biomass Stages of Microalgae Aphanothece Halophytica Developed in Business Scale
}

\section{R. Monisha Miriam}

Udaya School of Engineering

Ajith J Kings ( $\nabla$ ajithjkings@gmail.com )

St Xavier's Catholic College of Engineering

R. Edwin Raj

National Rail and Transportation Institute

K. Prakash Shyam

VVD and Sons Private Limited

M. Adhi Viswanathan

Pinnacle Biosciences

\section{Research Article}

Keywords: Microalgae, optimization, oil extraction, dry basis, wet basis

Posted Date: October 25th, 2021

DOI: https://doi.org/10.21203/rs.3.rs-998943/v1

License: (c) (1) This work is licensed under a Creative Commons Attribution 4.0 International License. Read Full License 


\section{Abstract}

Worldwide, people are accepting a sustainable, renewable and economical source for biofuel production without affecting the environmental concerns. Microalgae can overcome problems with reasonable solutions along with higher lipid content, carbon neutrality, biomass productivity and utilization of feed supplements. Picking a distinctive strain is vital and the value depends on its micro, macro nutrients and its photosynthesis efficiency. Extracting oil from the different phases of microalgal biomass is a tedious process. Presently, halophilic Aphanothece halophytica was mass cultivated in raceway ponds using organic and inorganic nutrients. Microalgal biomass was harvested using novel organic flocculant and oil extraction was done through wet and dry basis based on solvent polarity. The process parameters were optimized for maximum lipid productivity using RSM and the empirical model was significantly analysed by analysis of variance. In wet basis, maximum lipid yield was $29.3 \%$, where the reaction temperature, reaction time, biomass-to-solvent ratio and mixing intensity are $68^{\circ} \mathrm{C}, 190 \mathrm{~min}, 9: 1$ and $300 \mathrm{rpm}$ respectively. In dry basis, lipid yield $27.5 \%$ was achieved using 12:1 biomass-to-solvent ratio and mixing intensity was $300 \mathrm{rpm}$ for $190 \mathrm{~min}$ at $68^{\circ} \mathrm{C}$. Then, the lipid was characterized by GCMS to identify the fatty acid composition to identify the right combination of fatty acid profile for further studies.

\section{Introduction}

Due to increase in fuel cost and continuous depletion of crude oil associated with environmental issues there is an urge to search an alternative which is clean, renewable and sustainable. Recent studies established positive results in microalgal fuel with environment concern and fossil fuels dependence. Microalgae are promising source for high lipid content which has fast growing rate and can cultivate in waste surface. Moreover, a microalga does not compete with food feedstocks and makes it a stimulating substitute for popular food and non-food crops [1, 2].

Energy recovery from microalgae is a necessary footstep to enhance and improve the sustainability and economic competitiveness. Releasing the lipid from the complex structure of microalgal cell wall is a major tricky in the extraction process $[3,4]$. Usually, microalgal biomass was subjected to taking out the lipids by mechanical pressing and organic solvents. In mechanical pressing, the yield of oil depends on the extraction technique employed such as screw / piston press, extruder and expander, pulverization using mortar, etc $[5,6]$. The method of organic solvent extraction employs 'like dissolving like' concept of basic chemistry to extract lipid from microalgae using solvents [7].

In the cell membrane of microalgae, neutral lipids are found as a complex with polar lipids and are strongly linked with the proteins through hydrogen bonds. Ideal solvent must be highly specific and volatile in order to ensure low energy distillation for extracting lipid from the solvent [8]. The non-polar solvents used for lipid extraction from microalgae biomass include hexane, benzene, toluene, diethylether, chloroform, chloroethane and dichloromethane. Similarly, the polar solvents used are methanol, ethanol, acetone, ethyl acetate and 2-propanol. The non-polar solvents disrupt the hydrophobic interactions between non-polar and neutral lipids, whereas the polar solvent disrupts the polar lipids. Addition of both 
polar and non-polar organic solvent ensures, complete extraction of all neutral lipid (free standing globules and membrane associated complexes). The combinations of polar and non-polar solvent generally used are chloroform/methanol, n-hexane/ethanol, n-hexane/2-propanol, chloroethane/methanol, dichloroethane/ethanol and acetone/dichloromethane [9, 10]. However, chloroform/ methanol $(1: 2 \mathrm{v} / \mathrm{v})$ is the mostly used organic solvent because of the reduced extraction time and high yield.

The remaining water in the algal cells acts as a ternary component, permitting complete extraction of both neutral and polar lipids. In this method complete drying of biomass is not needed, since separation happens by biphasic partitioning. The lower phase (chloroform and some methanol) contains lipid (neutral and polar), while the upper aqueous phase (water, methanol) contains non lipid components (proteins and carbohydrates) [10].

One hypothesis speculates that the presence of residual moisture in microalgal biomass unfavourably affects the lipid extraction efficiency. In such school of thought, the water forms a barrier and inhibits effective lipid mass transfer from cells to the organic solvent. So drying of microalgal concentrate is recommended prior to lipid extraction [9]. Another hypothesis postulates that the presence of residual moisture content in microalgal biomass will enhance lipid extraction efficiency. The principle is that the water swells the cells and allows better solvent access to the lipids and states that drying of microalgae before lipid extraction is unnecessary and may hinder the lipid extraction [11].

Soxhlet or hexane solvent extraction method can be used either alone or in combination with oil press method. Oil extraction in batch mode needs large amount of organic solvent, whereas continuous mode replenishes the biomass with organic solvent and reduces the solvent consumption $[12,9]$. This method is quite expensive and has to be handled carefully as it involves chemicals. Benzene is a carcinogen and can lead to explosion hazard also. Hexane is less efficient than chloroform which is less toxic and has low affinity towards non lipid contaminants [13]. Bligh and Dyer's method is used for both dry and wet mode of oil extraction [14] where the ratio of chloroform/methanol is maintained around 2:1. After mixing the solvent and the biomass, it is homogenized with another same quantity of solvent. The method of centrifugation separates the biphase layer (lipid in chloroform and methanol in water) in the process and the lipid is separated finally by fractional distillation $[15,16]$.

There is an emerging green technology for oil extraction where super critical carbondioxide $\left(\mathrm{SCCO}_{2}\right)$ is used as the primary solvent at a critical pressure of $7.4 \mathrm{MPa}$ and at lower critical temperature of $31.3^{\circ} \mathrm{C}$ $[17,18]$. The factors affecting this process include the pressure, the temperature and the fluid flow rate. $\mathrm{SCCO}_{2}$ has high solvatic power and is less toxic, but the high infrastructure requirements and the operating cost are the main challenges in this process $[19,20$,$] . A contrasting result has been reported in a$ comparative study between $\mathrm{SCCO}_{2}$ and Bligh and Dyer method for extracting heterotrophically cultured microalgae $C$. cohnii $[21,22]$. The lipid yield obtained from Bligh and Dyer procedure is nearly double compared to this method. It is noted that the microalgae strains and culture conditions play a crucial role in the determination of appropriate lipid extraction method. The microalgal residues are rich in 
carbohydrates, proteins and pigment $[23,24,25,26,27]$. They can be further processed into biomethane, bioethanol, biobutanol, etc. [28, 29, 30,31,32,33]. It is also used to produce valuable products like docosahexaenoic acid (DHA), carotenoids, drugs, food and feed additives [34, 35, 36].

In this work, microalgae Aphanothece halophytica was isolated from saltpan area and be cultivated in Jaworski's medium. Then, the culture was mass propagated using organic and inorganic combo nutrients in open raceway ponds. The lipid was extracted by two ways 1) from wet biomass and 2) dry biomass. According to the polarity, solvents were selected for both methods. The extraction process parameters such as extraction time, temperature, biomass-to-solvent ratio and mixing intensity were optimized by response surface methodology (RSM). The lipid was quantified and proposed a better practice for commercialization. Finally, lipid was characterized by gas chromatography to obtain the fatty acid signature for further processes.

\section{Materials And Methods}

The working methodology of the lipid extraction enhancement process from the microalgae isolation is charted in the Fig. 1.

\subsection{Microalgae culture Protocol}

Water samples were collected from saltpan $\left(8.1089^{\circ} \mathrm{N}, 77.4667^{\circ} \mathrm{E}\right)$, Kanyakumari District and the physiochemical characteristics were analyzed. The samples were enriched by using standard marine Jaworski's medium followed by serial dilution. Then purified by quadrant streaking using solid medium. Then the inoculated cultures were incubated at $25^{\circ} \mathrm{C}$ with an illumination of 2500 lux for $12: 12 \mathrm{~h}$ light/dark at pH 8.2 for about one month in the laboratory. Morphological depiction was done using a microscope and Nile Red staining was employed for visualizing the presence of lipid which was published in Elsevier [37].

\subsection{Oil extraction procedure}

Extraction of lipid was done by Bligh and Dyer method from the dried biomass. Powdered biomass of about $1 \mathrm{~g}$ was mixed with $30 \mathrm{ml}$ of chloroform/methanol (2:1) and was gently agitated in an orbital shaker at $100 \mathrm{rpm}$ for $20 \mathrm{~min}$ and then centrifuged at $2000 \mathrm{rpm}$ for $10 \mathrm{~min}$ to separate the oil extract and the microalgal pellet. The resultant oil extract was allowed to evaporate at $40^{\circ} \mathrm{C}$ and then kept in hot air oven at $70^{\circ} \mathrm{C}$ for $2 \mathrm{~h} \mathrm{[16].} \mathrm{Then} \mathrm{the} \mathrm{lipid} \mathrm{was} \mathrm{quantified} \mathrm{and} \mathrm{the} \mathrm{lipid} \mathrm{productivity} \mathrm{was} \mathrm{estimated} \mathrm{[38].}$

\subsection{Large scale propagation methodology 2.3.1. Preparation of Inoculum}

Ten percentage of the log phase microalgal culture was inoculated in the 1 I flask containing the media, followed by 10 I flask, 20 I flask and 200 I glass tank with the same conditions [37]. The seed culture for cultivation in open raceway ponds was separately grown in 500 I capacity round cement tanks. Initially 
the tank was thoroughly rinsed with $5 \%$ sodium hypochlorite in tap water and kept overnight in closed condition. The tank was again rinsed with tap water and exposed to sunlight for $12 \mathrm{~h} .175 \mathrm{ml}$ of seaweed extract + NPK solution along with 350 I of filtered sea water was loaded onto the tank, where 35 I of log phase inoculum was added, which was grown in a glass tank. The $\mathrm{pH}$ and the salinity were maintained at 8.2 and 60 ppt respectively.

\subsubsection{Raceway Pond Cultivation}

For mass propagation, the microalgae were cultivated in open raceway ponds of size $7.6 \times 1.2 \times 0.4 \mathrm{~m}$ having the total volume of 3500 I capacity. The microalgal growth medium was prepared with the optimized condition of seaweed extract + NPK in 3300 I of filtered sea water. $10 \%$ of starter inoculum culture from the round cement tank was added to initiate growth in the raceway pond. The medium was continuously agitated using a paddle wheel at $36 \mathrm{rpm}$, to prevent algal culture sedimentation and ensure uniform acquaintance of all microalgae to light and nutrients. Gentle agitation is needed to avoid thermal stratification and to enhance $\mathrm{CO}_{2}$ distribution. Culture purity was ensured through regular microscopic examination.

\subsubsection{Mode of cultivation}

The mode of cultivation is semi-continuous and provides partial periodic harvesting. Initially $25 \%$ of the microalgal culture was collected on the peak day and then on daily basis. The $\mathrm{pH}$ was maintained at 8.2 and the volume of culture harvested was replenished with appropriate amount of fresh nutrient to maintain the optimum culture conditions.

\subsection{Biomass Harvesting}

The harvesting of microalgal cells was done by bio flocculation process using organic flocculant, commercial Neem plus. Experimental investigation was done to optimize the required flocculant dose by varying the concentration as $0.001,0.002,0.003,0.004,0.005 \mathrm{ml} / \mathrm{l}$ and the optimized dose was adopted for biomass harvesting.

\subsection{Lipid Extraction Procedure}

Oil extraction was done on wet basis as well as on dry basis. In wet method, the harvested biomass was dewatered with cheese cloth and kept in an autoclave for $20 \mathrm{~min}$ at $121^{\circ} \mathrm{C}$ and $15 \mathrm{psi}$ pressure whereas in dry mode of extraction, after pressing the harvested biomass with cheese cloth, it was spread on polythene sheets and sun dried followed by microwave oven drying at $50^{\circ} \mathrm{C}$. The dried microalgal biomass was then powdered by using a pulveriser. The moisture content of the microalgal biomass was determined for every process.

Selection of appropriate solvent is important for efficient and economical extraction of algal oil. Based on the literature and confirmation test chloroform/methanol (2:1), a non-polar/ polar solvent mixture was selected. The properties of chloroform and methanol are indicated in Table 3.1. 
Table 1

Properties of chloroform and methanol solvent

\begin{tabular}{|lll|}
\hline Property & Chloroform & Methanol \\
\hline Chemical formula & $\mathrm{CHCl}_{3}$ & $\mathrm{CH}_{3} \mathrm{OH}$ \\
\hline Nature & Non polar solvent & Polar solvent \\
\hline Molar mass & $119.37 \mathrm{~g} / \mathrm{mol}$ & $32.04 \mathrm{~g} / \mathrm{mol}$ \\
\hline Appearance & Colorless & Colorless \\
\hline Odor & Ethereal odor & Alcoholic odor \\
\hline Boiling point & $61^{\circ} \mathrm{C}$ & $65^{\circ} \mathrm{C}$ \\
\hline Melting point & $-63^{\circ} \mathrm{C}$ & $-98^{\circ} \mathrm{C}$ \\
\hline Density & $1.492 \mathrm{~g} / \mathrm{cm}^{3}$ & $0.791 \mathrm{~g} / \mathrm{cm}^{3}$ \\
\hline Auto ignition point & $455^{\circ} \mathrm{C}$ & $982^{\circ} \mathrm{C}$ \\
\hline
\end{tabular}

\subsubsection{Extraction Setup}

The experimental setup comprises of a three neck round bottomed flask and a hot plate temperature controlled magnetic stirrer (Fig. 2). The large neck of the flask was allied to the reflux condenser and the other two ports are meant for a thermometer and sampling. Designed quantity of solvent was added with $25 \mathrm{~g}$ of biomass and heated at various designed temperature for different duration at various intensity. After the process, the blend was permitted to cool and filtered to remove the biomass. The filtrate was distilled using rotary evaporator to separate the lipid from the solvent and it was quantified after removing the moisture by heating at $105^{\circ} \mathrm{C}$ for $1 \mathrm{~h}$. Then, the acid value was found through the titration process to confirm the steps involved in the biodiesel conversion process.

\subsubsection{Optimization of microalgal oil extraction}

A three level four factor Box-Behnken Design (BBD) was employed in the optimization process, with 29 sets of experiment, contains 5 central points and 24 axial points. The extraction process parameters such as biomass-to-solvent ratio, mixing intensity, extraction temperature and time are to be enhancing the exploit of oil yield. The range and level of the factors involved in oil extraction for wet and dry biomass is shown in Table 2.

Table 2. The ranges and levels of the lipid extraction process parameters using wet and dry biomass 


\begin{tabular}{|c|c|c|c|c|c|}
\hline \multirow[t]{2}{*}{ Biomass phases } & \multirow[t]{2}{*}{ Process parameters } & \multirow[t]{2}{*}{ Unit } & \multicolumn{3}{|c|}{ Range and level } \\
\hline & & & $\operatorname{Low}(-1)$ & Medium (0) & High (+1) \\
\hline \multirow[t]{4}{*}{ Wet biomass } & Biomass-to-solvent ratio & $(v / w)$ & $4: 1$ & $8: 1$ & $12: 1$ \\
\hline & Extraction time & $\min$ & 60 & 180 & 300 \\
\hline & Extraction temperature & $\left({ }^{\circ} \mathrm{C}\right)$ & 55 & 65 & 75 \\
\hline & Mixing intensity & rpm & 200 & 450 & 700 \\
\hline \multirow[t]{4}{*}{ Dry biomass } & Biomass-to-solvent ratio & $(v / w)$ & $6: 1$ & $10: 1$ & $14: 1$ \\
\hline & Extraction time & $\min$ & 60 & 210 & 360 \\
\hline & Extraction temperature & $\left({ }^{\circ} \mathrm{C}\right)$ & 55 & 65 & 75 \\
\hline & Mixing intensity & rpm & 300 & 600 & 900 \\
\hline
\end{tabular}

\subsection{Lipid characterization by GC-MS}

Perkin Elmer Clarus 500 spectrometry was used to find the fatty acid profile of the microalgal lipid with mass detector (Turbo mass gold- Perkin Elmer) and column ELITE 1-100\% Dimethyl poly siloxane, $(30 \times 0.25 \mathrm{~mm} \times 1 \mu \mathrm{mdf})$ under nitrogen atmosphere $(1 \mathrm{ml} / \mathrm{min})$. Primarily, the temperature was retained at $110^{\circ} \mathrm{C}$ for $2 \mathrm{~min}$ and then it was increased at the rate of $5^{\circ} \mathrm{C} / \mathrm{min}$ till $208^{\circ} \mathrm{C} .2 \mu \mathrm{l}$ of the sample was given to the spectrometer which is fitted with the mass spectrometer. The profile of the fatty acid was identified through the percentage of peak areas with their retention time.

\section{Results And Discussion}

\subsection{Mass propagation analysis}

The isolated Aphanothece halophytica cultivated in the lab scale was then cultured in outdoor open raceway ponds (Fig. 3). This process has better possibility to achieve higher biomass production [39]. The best medium recognized after methodical study for exploiting the oil productivity was seaweed extract + NPK with $0.5 \mathrm{ml} / \mathrm{l}, 0.05 \mathrm{~g} / \mathrm{l}$ urea, $0.5 \mathrm{~g} / \mathrm{I} \mathrm{SSP}$ and $0.5 \mathrm{~g} / \mathrm{I} \mathrm{MOP} \mathrm{[37].} \mathrm{In} \mathrm{general,} \mathrm{open} \mathrm{pond} \mathrm{system}$ needs specific environment for a selected species to avoid contamination and pollution from other microbial species [40, 41, 42]. Monoculture cultivation of Aphanothece halophytica was possible since it thrives very well in high salinity conditions. Similarly such successful large scale monoculture cultivation of Acutodesmus dimorphus was reported in extreme halophilic condition as well [43]. It is also reported that heterotrophic cultivation of microalgae results in higher biomass and lipid content [44].

The biomass was harvested on the log max day (20th day) using flocculation method by organic commercial neem plus solution which is a low energy consuming method to harvest microalgae. Preliminary experiments were conducted to optimize the required dose of organic flocculant. The observed outcomes are given in Table 3, which reveals that, the concentration of $0.002 \mathrm{ml} / \mathrm{l}$ of flocculate 
was enough for harvesting the maximum microalgal biomass within $180 \mathrm{sec}$. being an organic flocculant, it will avoid the usage of costly toxic chemicals for microalgal harvesting. Similar methodology has been used in the used in many microalgal biomasses harvesting using Chitosan [45, 46]. For example, microalgae Microcytis aeruginosa was effectively harvested using chitosan, with an efficiency of $99.2 \%$ [47] It was reported that harvesting of Chlorella vulgaris using $120 \mathrm{mg} / \mathrm{l}$ of chitosan gave an efficiency of $92 \pm 0.4 \%$ within $180 \mathrm{~s}$ [48]. Moreover, organically flocculated medium can be reused effectively without affecting microalgal growth. This will reduce the overall production cost by avoiding the process for water treatment and purification [46, 49]. In the present work, the higher yield 300 $\mathrm{g}$ of dried biomass per day was attained after cultivation of Aphanothece halophytica in 6 raceway ponds.

Table 3

Effectiveness of biomass harvesting using organic flocculant, neem plus

\begin{tabular}{|lll|}
\hline $\begin{array}{lll}\text { Neem plus } \\
(\mathrm{ml} / \mathrm{l})\end{array}$ & $\begin{array}{l}\text { Harvested biomass } \\
\mathbf{( \% )}\end{array}$ & $\begin{array}{l}\text { Time of harvesting } \\
(\mathbf{s})\end{array}$ \\
\hline 0.001 & 94 & 250 \\
\hline 0.002 & 99.4 & 180 \\
\hline 0.003 & 99.1 & 180 \\
\hline 0.004 & 99 & 179 \\
\hline 0.005 & 98 & 179 \\
\hline 3.2. Optimization of lipid extraction parameters
\end{tabular}
3.2.1. Lipid Extraction from Wet Biomass

The wet biomass yield obtained after harvesting is shown in Fig. 4. The major parameters influencing the extraction of lipid from wet biomass are temperature, time, biomass-to-solvent ratio and mixing intensity. The range and level of each parameter were confirmed by pilot experiments in corroboration with literature. The designed experiments and the combination of process parameter along with their corresponding lipid yield are tabulated in Table 4. 
Table 4

The Box-Behnken designed process parameters (BBD) for optimizing the extraction process on wet basis and their corresponding lipid yield

\begin{tabular}{|c|c|c|c|c|c|}
\hline $\begin{array}{l}\text { No. of } \\
\text { run }\end{array}$ & $\begin{array}{l}\text { A:Extraction } \\
\text { Temperature } \\
\left({ }^{\circ} \mathrm{C}\right)\end{array}$ & $\begin{array}{l}\text { B:Extraction } \\
\text { time } \\
(\mathrm{min})\end{array}$ & $\begin{array}{l}\text { C: biomass-to- } \\
\text { solvent ratio } \\
(\mathrm{v} / \mathrm{w})\end{array}$ & $\begin{array}{l}\text { D:Mixing } \\
\text { intensity } \\
\text { (rpm) }\end{array}$ & $\begin{array}{l}\text { Lipio } \\
\text { yield } \\
(\%)\end{array}$ \\
\hline 1 & 65 & 60 & 8 & 700 & 17.4 \\
\hline 2 & 65 & 180 & 4 & 700 & 8 \\
\hline 3 & 55 & 300 & 8 & 450 & 26.4 \\
\hline 4 & 65 & 180 & 8 & 450 & 28.8 \\
\hline 5 & 65 & 180 & 8 & 450 & 28.5 \\
\hline 6 & 65 & 60 & 4 & 450 & 0.7 \\
\hline 7 & 65 & 300 & 12 & 450 & 28.9 \\
\hline 8 & 65 & 180 & 12 & 700 & 25.8 \\
\hline 9 & 75 & 60 & 8 & 450 & 17.5 \\
\hline 10 & 55 & 60 & 8 & 450 & 10.5 \\
\hline 11 & 65 & 180 & 12 & 200 & 26.9 \\
\hline 12 & 55 & 180 & 8 & 700 & 20.2 \\
\hline 13 & 65 & 300 & 8 & 700 & 27.5 \\
\hline 14 & 65 & 180 & 4 & 200 & 7.22 \\
\hline 15 & 75 & 180 & 8 & 200 & 21.8 \\
\hline 16 & 75 & 300 & 8 & 450 & 22.5 \\
\hline 17 & 55 & 180 & 4 & 450 & 5.1 \\
\hline 18 & 65 & 60 & 12 & 450 & 19.7 \\
\hline 19 & 65 & 60 & 8 & 200 & 17.3 \\
\hline 20 & 75 & 180 & 4 & 450 & 4.4 \\
\hline 21 & 65 & 180 & 8 & 450 & 28.7 \\
\hline 22 & 65 & 180 & 8 & 450 & 28.9 \\
\hline 23 & 75 & 180 & 8 & 700 & 22.9 \\
\hline 24 & 65 & 180 & 8 & 450 & 28.7 \\
\hline 25 & 55 & 180 & 12 & 450 & 21.7 \\
\hline
\end{tabular}




\begin{tabular}{|llllll|}
\hline $\begin{array}{l}\text { No. of } \\
\text { run }\end{array}$ & $\begin{array}{l}\text { A:Extraction } \\
\text { Temperature } \\
\left({ }^{\circ} \mathrm{C}\right)\end{array}$ & $\begin{array}{l}\text { B:Extraction } \\
\text { time } \\
(\mathrm{min})\end{array}$ & $\begin{array}{l}\text { C: biomass-to- } \\
\text { solvent ratio } \\
(\mathrm{v} / \mathrm{w})\end{array}$ & $\begin{array}{l}\text { D:Mixing } \\
\text { intensity } \\
(\mathrm{rpm})\end{array}$ & $\begin{array}{l}\text { Lipid } \\
\text { yield } \\
(\%)\end{array}$ \\
\hline 26 & 65 & 300 & 4 & 450 & 11.6 \\
\hline 27 & 55 & 180 & 8 & 200 & 21.4 \\
\hline 28 & 65 & 300 & 8 & 200 & 28 \\
\hline 29 & 75 & 180 & 12 & 450 & 25.3 \\
\hline
\end{tabular}

The developed empirical model was verified for its significance and aptness by analysis of variance (ANOVA). The model p-value was less than 0.0001 indicating statistical significance. The analysis of variance results is tabulated in Table 5. The lack of fit was satisfactorily low, which is 0.1359 and so the model is fitted to the investigational data. 
Table 5

Analysis of variance (ANOVA) results of the model to optimize the oil extraction process on wet biomass basis

\begin{tabular}{|c|c|c|c|c|c|}
\hline Source of variables & $\begin{array}{l}\text { Sum of } \\
\text { squares }\end{array}$ & Df & $\begin{array}{l}\text { Mean } \\
\text { square }\end{array}$ & F-value & P-value Pro>F \\
\hline Model & 2080.01 & 14 & 148.57 & 2616.37 & $\begin{array}{l}<0.0001 \\
\text { significant }\end{array}$ \\
\hline A-Extraction Temperature & 6.9 & 1 & 6.9 & 121.52 & $<0.0001$ \\
\hline B-Extraction time & 319.3 & 1 & 319.3 & 5622.91 & $<0.0001$ \\
\hline $\begin{array}{l}\text { C- biomass-to-solvent } \\
\text { ratio }\end{array}$ & 1033.79 & 1 & 1033.79 & 18205.14 & $<0.0001$ \\
\hline D-Mixing intensity & 0.056 & 1 & 0.056 & 0.99 & 0.3374 \\
\hline$A B$ & 29.7 & 1 & 29.7 & 523.06 & $<0.0001$ \\
\hline AC & 4.62 & 1 & 4.62 & 81.4 & $<0.0001$ \\
\hline$A D$ & 1.32 & 1 & 1.32 & 23.29 & 0.0003 \\
\hline $\mathrm{BC}$ & 0.64 & 1 & 0.64 & 11.27 & 0.0047 \\
\hline BD & 0.09 & 1 & 0.09 & 1.58 & 0.2286 \\
\hline$C D$ & 0.88 & 1 & 0.88 & 15.56 & 0.0015 \\
\hline$A^{2}$ & 174.16 & 1 & 174.16 & 3066.97 & $<0.0001$ \\
\hline$B^{2}$ & 110.73 & 1 & 110.73 & 1949.94 & $<0.0001$ \\
\hline$c^{2}$ & 581.3 & 1 & 581.3 & 10236.81 & $<0.0001$ \\
\hline$D^{2}$ & 28.38 & 1 & 28.38 & 499.75 & $<0.0001$ \\
\hline Residual & 0.79 & 14 & 0.057 & - & - \\
\hline Lack of fit & 0.71 & 10 & 0.071 & 3.21 & $\begin{array}{l}0.1359 \\
\text { not significant }\end{array}$ \\
\hline Pure Error & 0.088 & 4 & 0.022 & - & - \\
\hline Cor Total & 2080.81 & 28 & - & - & - \\
\hline
\end{tabular}

The $\mathrm{R}^{2}$ value, 0.9996 indicates good pact between the foreseen and the actual yield (Fig. 5). The Pred RSquare value of 0.9980 was in reasonable agreement with the Adj R-Square value of 0.9992. In this model, the ratio is 168.512 which indicates the adequacy of the signal to be used in the design space.

In addition to this, the normal probability plot of the residuals shows that the errors are spread in normal to a straight line insignificantly (Fig. 6). The Fig. 7, the residuals versus predicted response displays that 
the spread is even across all points approving the competence of the model over its range [50].

The percentage of oil yield on wet basis predicted by the model in terms of coded factors is given in equation 1.

Yield $=28.72+0.76 A+5.16 B+9.28 C-0.068 D-2.72 A B+1.07 A C+0.57 A D-0.40 B C-0.15 B D-$ $0.47 C D-5.18 A^{2}-4.13 B^{2}-9.47 C^{2}-2.09 D^{2}(1)$

Extraction of lipid from wet microalgal biomass diminishes the energy requirement for the drying process $[51,52]$. The perturbation plot (Fig. 8) depicts the effects of an extraction parameter on the lipid yield in the designed space while keeping the other process parameters constant at their midpoint. The steep positive slope $(\mathrm{C}-\mathrm{C})$ was observed for biomass-to-solvent ratio towards oil yield up to +0.5 reference indicates that as the solvent quantity increases, the oil yield increases. However, the response gets saturated around 8:1 biomass-to-solvent ratio and further addition of solvent was redundant. The plot for the reaction time shows that as the reaction time rises there was increase in yield and get saturated around $300 \mathrm{~min}$. The reaction temperature was optimum near the boiling point of methanol $\left(65^{\circ} \mathrm{C}\right)$ and deviation from this temperature shows a negative effect on biodiesel yield. The mixing intensity was to be kept at optimum for enhancing the reaction to maximize the yield. The influence of this parameter in the designed range was very minimum. Some researchers have reported that the negative influence of moisture on oil yield, which can be negated with pre-treatments by making the intracellular lipids more readily available for extraction by solvent $[53,54]$.

\subsubsection{Influence of solvent biomass ratio and extraction time (wet basis)}

The solvent, Chloroform/methanol for oil extraction is very effective to both neutral and polar lipids when compared with other solvents $[55,56]$. For example, the non-polar solvent, hexane (4:1) dissolves only the non-polar lipids in the microalgae with an oil yield of $9.4 \%$ from olive foot cake [57]. Solvent mixture of toluene, n-hexane, ethanol and methanol was used to extract oil from sewage sludge, where the higher yield was obtained for the solvent biomass ratio of 5:1 [58]. Fig. 9 shows the 3D surface plot and corresponding contour plot for oil yield with respect to solvent ratio and time with a minimum of 7:1 solvent ratio was needed for higher yield when allowed to react for more than $150 \mathrm{~min}$. The optimized empirical model predicts a maximum yield of $28.9 \%$ at $8: 1$ solvent biomass ratio. It was renowned that as the reaction time increases the oil yield increases and get saturated as time reaches maximum level in the designed domain. The optimized time considering the correlation effects among the process parameters was $190 \mathrm{~min}$.

\subsubsection{Influence of extraction temperature and mixing intensity (wet basis)}

Solvent based extraction allows complete extraction of oil when carried out closer to the boiling point of the solvent $[59,60]$. The influence of temperature on oil extraction from A. halophytica wet biomass was 
investigated between $55^{\circ} \mathrm{C}$ and $75^{\circ} \mathrm{C}$. The $3 \mathrm{D}$ surface plot and the matching contour plot show that the outcome of reaction temperature and stirring intensity on the lipid yield from wet biomass (Fig. 10). It was well-known that the oil yield was optimum around the boiling point of methanol $\left(65^{\circ} \mathrm{C}\right)$, where the effectiveness of the solvent was maximum. At optimum temperatures the evaporation rate and the condensation rate (reflux) balance perfectly for maximizing the oil yield. Temperature higher than the optimum leads to loss of solvents by evaporation. The solvents after extraction are recovered by simple distillation process.

Proper stirring was important to mix the biomass with the solvent for effective chemical reaction to occur and to enhance the oil extraction. Fig. 10 shows that the oil yield increases as the stirring speed increases and was appropriate around $450 \mathrm{rpm}$. However, the optimum stirring speed for maximum oil yield by considering the interactive effects of other process parameter was $300 \mathrm{rpm}$.

The optimum process parameters of oil extraction were statistically derived from the developed empirical model to make the most of the oil yield in a short time. The finest value of the predicted process parameters is listed in Table 6.

Table 6

The predicted optimized process parameters value for maximizing the oil extraction in short span (wet basis)

\begin{tabular}{|lllll|}
\hline $\begin{array}{l}\text { Reaction temperature } \\
\left({ }^{\circ} \mathrm{C}\right)\end{array}$ & $\begin{array}{l}\text { Reaction } \\
\text { time } \\
(\mathrm{min})\end{array}$ & $\begin{array}{l}\text { Solvent biomass ratio } \\
(\mathrm{v} / \mathrm{w})\end{array}$ & $\begin{array}{l}\text { Mixing intensity } \\
(\mathrm{rpm})\end{array}$ & $\begin{array}{l}\text { Oil yield } \\
(\%)\end{array}$ \\
\hline 68 & 190 & $9: 1$ & 300 & 29.3 \\
\hline
\end{tabular}

\subsubsection{Lipid Extraction from Dried Biomass}

The obtained dried biomass obtained is shown in Fig. 11. The parameters influencing the extraction of lipid from dry biomass are the same as that for the extraction on wet basis. The designed process parameter combinations and their corresponding lipid yield are given in Table 7. 
Table 7

The Box-Behnken design for optimizing the extraction process parameters on dry basis and their corresponding lipid yield

\begin{tabular}{|c|c|c|c|c|c|}
\hline $\begin{array}{l}\text { No. of } \\
\text { run }\end{array}$ & $\begin{array}{l}\text { A:Extraction } \\
\text { Temperature } \\
\text { (C) }\end{array}$ & $\begin{array}{l}\text { B:Extraction } \\
\text { time } \\
(\min )\end{array}$ & $\begin{array}{l}\text { C:solvent biomass } \\
\text { ratio } \\
(v / w)\end{array}$ & $\begin{array}{l}\text { D:Mixing } \\
\text { intensity } \\
\text { (rpm) }\end{array}$ & $\begin{array}{l}\text { Lipid } \\
\text { yield } \\
\text { (\%) }\end{array}$ \\
\hline 1 & 55 & 60 & 10 & 600 & 7 \\
\hline 2 & 65 & 360 & 6 & 600 & 17.9 \\
\hline 3 & 65 & 360 & 10 & 900 & 24.9 \\
\hline 4 & 65 & 60 & 6 & 600 & 5 \\
\hline 5 & 55 & 360 & 10 & 600 & 21.7 \\
\hline 6 & 75 & 210 & 6 & 600 & 10.8 \\
\hline 7 & 65 & 210 & 10 & 600 & 27.1 \\
\hline 8 & 65 & 60 & 10 & 300 & 12.2 \\
\hline 9 & 55 & 210 & 14 & 600 & 16.8 \\
\hline 10 & 65 & 210 & 10 & 600 & 27.2 \\
\hline 11 & 75 & 360 & 10 & 600 & 24.4 \\
\hline 12 & 65 & 210 & 10 & 600 & 27.4 \\
\hline 13 & 65 & 60 & 10 & 900 & 11.4 \\
\hline 14 & 65 & 60 & 14 & 600 & 15.1 \\
\hline 15 & 65 & 210 & 14 & 300 & 22.4 \\
\hline 16 & 55 & 210 & 10 & 300 & 14.1 \\
\hline 17 & 75 & 210 & 14 & 600 & 24.2 \\
\hline 18 & 65 & 360 & 10 & 300 & 24.7 \\
\hline 19 & 65 & 210 & 6 & 900 & 11.5 \\
\hline 20 & 65 & 210 & 6 & 300 & 12 \\
\hline 21 & 75 & 210 & 10 & 300 & 20 \\
\hline 22 & 75 & 210 & 10 & 900 & 17.6 \\
\hline 23 & 65 & 360 & 14 & 600 & 27.4 \\
\hline 24 & 75 & 60 & 10 & 600 & 12.5 \\
\hline 25 & 65 & 210 & 10 & 600 & 27.3 \\
\hline
\end{tabular}




\begin{tabular}{|llllll|}
\hline $\begin{array}{l}\text { No. of } \\
\text { run }\end{array}$ & $\begin{array}{l}\text { A:Extraction } \\
\text { Temperature }\end{array}$ & $\begin{array}{l}\text { B:Extraction } \\
\text { time } \\
(\mathrm{C})\end{array}$ & $\begin{array}{l}\text { C:solvent biomass } \\
\text { ratio } \\
(\mathrm{min})\end{array}$ & $\begin{array}{l}\text { D:Mixing } \\
\text { intensity } \\
(\mathrm{v} / \mathrm{w})\end{array}$ & $\begin{array}{l}\text { Lipid } \\
\text { yield }\end{array}$ \\
\hline 26 & 65 & 210 & 14 & 900 & $(\%)$ \\
\hline 27 & 65 & 210 & 10 & 600 & 22.1 \\
\hline 28 & 55 & 210 & 6 & 600 & 27.2 \\
\hline 29 & 55 & 210 & 10 & 900 & 9.7 \\
\hline
\end{tabular}

The developed empirical model from the experiments on dry basis was verified for their significance and fitness by analysis of variance (ANOVA) and results were tabulated in Table 8. The model p-value was less than 0.0001 indicating statistical significance. The lack of fit was low enough to ignore the value of 0.0522 that shows the model was perfectly fitted with the investigational data. 
Table 8

Analysis of variance (ANOVA) results of the model to optimize the lipid extraction process dry biomass basis

\begin{tabular}{|c|c|c|c|c|c|}
\hline Source of variables & Sum of squares & Df & Mean square & F-value & $\begin{array}{l}\text { P-value } \\
\text { Pro>F }\end{array}$ \\
\hline Model & 1362.7 & 14 & 97.34 & 1686.86 & $<0.0001$ \\
\hline $\begin{array}{l}\text { A-Extraction } \\
\text { Temperature }\end{array}$ & 51.25 & 1 & 51.25 & 888.24 & $<0.0001$ significant \\
\hline B-Extraction time & 505.7 & 1 & 505.7 & 8763.95 & $<0.0001$ \\
\hline C-solvent biomass ratio & 312.12 & 1 & 312.12 & 5409.14 & $<0.0001$ \\
\hline D-Mixing intensity & 0.52 & 1 & 0.52 & 9.03 & 0.0095 \\
\hline$A B$ & 1.96 & 1 & 1.96 & 33.97 & $<0.0001$ \\
\hline AC & 9.92 & 1 & 9.92 & 171.96 & $<0.0001$ \\
\hline$A D$ & 3.42 & 1 & 3.42 & 59.31 & $<0.0001$ \\
\hline $\mathrm{BC}$ & 0.063 & 1 & 0.063 & 1.08 & 0.3156 \\
\hline $\mathrm{BD}$ & 0.25 & 1 & 0.25 & 4.33 & 0.0562 \\
\hline $\mathrm{CD}$ & $1.00 \mathrm{E}-02$ & 1 & $1.00 \mathrm{E}-02$ & 0.17 & 0.6835 \\
\hline$A^{2}$ & 237.36 & 1 & 237.36 & 4113.46 & $<0.0001$ \\
\hline$B^{2}$ & 148.62 & 1 & 148.62 & 2575.62 & $<0.0001$ \\
\hline$c^{2}$ & 229.57 & 1 & 229.57 & 3978.58 & $<0.0001$ \\
\hline$D^{2}$ & 119.19 & 1 & 119.19 & 2065.64 & $<0.0001$ \\
\hline Residual & 0.81 & 14 & 0.058 & - & - \\
\hline Lack of fit & 0.76 & 10 & 0.076 & 5.81 & $\begin{array}{l}0.0522 \\
\text { not significant }\end{array}$ \\
\hline Pure Error & 0.052 & 4 & 0.013 & - & - \\
\hline Cor Total & 1363.51 & 28 & - & - & - \\
\hline
\end{tabular}

The $\mathrm{R}^{2}$ value of the model was 0.9994 indicates better pact between the predicted and the actual yield (Fig. 12). Further, the normal probability plot of the residuals shows that the errors were dispersed in normal by a straight line insignificantly (Fig. 13). The Fig. 14 shows the spread of residuals versus predicted response and it is uniform across all levels approving the suitability of the model over its range [45]. 
The percentage of oil yield on dry basis predicted by the model in terms of coded factors is given in Equation 2.

Yield $=27.24+2.07 A+6.49 B+5.10 C-0.21 D-0.70 A B+1.57 A C-0.92 A D-0.12 B C+0.25 B D+$ $0.050 C D-6.05 A^{2}-4.79 B^{2}-5.95 C^{2}-4.29 D^{2}(2)$

It was found that the efficiency of lipid extraction decreases with moisture content in biomass, hence the oil extraction analysis was done on dry basis also [61]. Most influential process parameters were studied by design of experiments and the corresponding experimental results were analyzed using ANOVA to draw conclusion from the model. The perturbation chart gives the effect of all parameters within the designed range, when the other parameters were kept constant on its middle value. Fig. 15 shows positive slopes (C-C and B-B) for solvent addition and reaction time with respect to the oil yield. Their influences get saturated at the higher range taken for study. However, the temperature and mixing intensities are optimum at their mid-range of the study.

\subsubsection{Influence of solvent to biomass ratio and reaction time (dry basis)}

The 3D plot and its corresponding contour plot are shown in Fig. 15. Chloroform/methanol solvent was an effective solvent for oil extraction on wet basis and the same was used here also. This solvent combination was successfully used for oil extraction from Chlorella pyrenoidosa dried biomass (1:1, v/v) [62] and for Botryococcus branni dried biomass at 2:1 (v/v) solvent biomass ratio [63]. Researchers have tested other solvent combinations hexane/isopropanol, dichloroethanol/ethanol, dichloroethane/ethanol, etc. and reported that chloroform/methanol as the best choice. When sufficient time (beyond $200 \mathrm{~min}$ ) was provided, higher oil yield was obtained when the solvent biomass ratio was kept in the range between 9 and 14. Considering the interactive effect of other process parameters the best ratio predicted from the empirical model was 12:1.

The time for the reaction was another important parameter deciding the oil yield. In this work, the influence of time on oil yield was examined from 60 to $360 \mathrm{~min}$ (Fig. 16) and it was noted that the oil yield increases by time. However, the influence of time minimizes and gets saturated around $300 \mathrm{~min}$. A minimum of 200 min was needed for better extraction and considering the interactive effect of other process parameters, the optimum time predicted by the model was $220 \mathrm{~min}$.

\subsubsection{Influence of extraction temperature and mixing intensity (dry basis)}

The reaction temperature for the oil extraction process was varied from $55^{\circ} \mathrm{C}$ to $75^{\circ} \mathrm{C}$. The oil yield increases from $9.1 \%$ at $55^{\circ} \mathrm{C}$ to around $27.4 \%$ for dried biomass at $65^{\circ} \mathrm{C}$, since the temperature influences the dissolving power of the solvent (Fig. 16). However, further increase in temperature beyond the boiling point of the solvent leads to decrease in oil yield. The optimum predicted temperature for maximum yield was $68^{\circ} \mathrm{C}$. The effect of stirring speed on oil extraction is shown in Fig. 17. The influence of varying the 
stirring speed on oil yield was very low with an F-value of only 9. Gentle stirring was important to ensure proper mixing for effective oil extraction. The optimum speed of the stirrer for the given condition was $600 \mathrm{rpm}$; varying the speed further away from this optimum value has resulted with negative effect on oil yield.

The optimum oil extraction process parameters on dry basis were statistically predicted from the empirical model to exploit the oil yield and are listed in Table 9.

Table 9

The predicted optimized process parameters to maximize the oil extraction on dry basis

\begin{tabular}{|lllll|}
\hline $\begin{array}{l}\text { Reaction temperature } \\
\left({ }^{\circ} \mathrm{C}\right)\end{array}$ & $\begin{array}{l}\text { Reaction time } \\
(\mathrm{min} .)\end{array}$ & $\begin{array}{l}\text { Solvent biomass ratio } \\
(\mathrm{v} / \mathrm{w})\end{array}$ & $\begin{array}{l}\text { Mixing intensity } \\
(\mathrm{rpm})\end{array}$ & $\begin{array}{l}\text { Oil yield } \\
(\%)\end{array}$ \\
\hline 68 & 220 & $12: 1$ & 600 & 27.5 \\
\hline
\end{tabular}

The free fatty acid content was found out by the titration method through the acid value. The acid value of the oil was $1.02 \mathrm{mg} \mathrm{KOH} / \mathrm{g}$, which indicates the FFA content is fairy $0.51 \%$. In the biodiesel conversion process, no need to consider the esterification process, since the acid value is less than $1 \mathrm{mg} \mathrm{KOH} / \mathrm{g}$. But most of the microalgae lipid contains more FFA value, which needs extra energy for further processing $[64,65]$.

\subsection{Oil characterization}

GC-MS was subjected to characterize the lipid to find the hydrocarbon compounds present in the composition. The fatty acid ranges from $\mathrm{C} 11: 0$ to $\mathrm{C} 26: 0$, which is dominated by monounsaturated fatty acids. Fig. 18 shows that the $32.39 \%$ of 11 -Octadecenoic acid methyl ester and $55.88 \%$ of 13 -Docosenoic acid methyl ester were dominated the monounsaturated fatty acid which offers the required oxidative stability and better combustion $[66,67,68]$. The existence of saturated and polyunsaturated fatty acids will limit the oxidation stability and makes the cold flow problems. Also, longer fatty acid carbon chains increase the cetane number to give better ignition and combustion characteristics $[69,70,71]$. Unsaturated fatty acid rises the fuel density and makes it less volatile, unfavourable to atomization, leads to carbon deposits in burning space. The greater acid value $(>1 \mathrm{mg} \mathrm{KOH} / \mathrm{g})$ of the biofuel destroys the rubber seals of the engine [72]. The inherent oxygen of hydrocarbons enhances the combustion properties and enables the decline in emission while using an alternative fuel in IC engine after conversion into biodiesel [73].

\section{Conclusion}

Finding a novel sustainable energy source is a tedious journey which needs insistent scientific work. The microalgae Aphanothece halophytica evidence a promising alternative energy resource which was mass propagated in open raceway ponds using an optimized medium. The biomass was harvested for the first time on 20th day (log max) and then on daily basis by employing organic neem plus flocculant which concentration was optimized as $0.002 \mathrm{ml} / \mathrm{l}$ for the maximum recovery of microalgal biomass within a 
short span of $180 \mathrm{~s}$. Oil extraction process parameters were optimized based on wet and dry basis using empirical models. The extraction time and solvent-biomass ratio are the major influencing factors along with temperature and mixing intensity. For wet biomass, high oil yield of $29.3 \%$ was achieved at $68^{\circ} \mathrm{C}$ in 190 min at 9:1 solvent-biomass ratio, while stirring at $300 \mathrm{rpm}$. Similarly on dry basis, the maximum oil yield of around $27.5 \%$ was achieved when the solvent-biomass ratio was $12: 1$, while allowing for 220 min at $68^{\circ} \mathrm{C}$ with a stirring speed of $600 \mathrm{rpm}$. The wet extraction procedure was more effective as it gives higher yield in less time with minimum solvent usage. The analysis of fatty acid profile by GC-MS shows the presence of $96.9 \%$ of monounsaturated fatty acid, $3.1 \%$ of saturated fatty acid and a negligible amount of polyunsaturated fatty acids to provide stability and good combustion phenomenon. The computed properties of algal biodiesel assure its usage in conventional diesel engines without any engine modification at less pollution.

\section{References}

1. Akubude VC, Nwaigwe KN, Dintwa E (2019) Production of biodiesel from microalgae via nanocatalyzed transesterification process: A review. Materials Science for Energy Technologies 2:216-225. https://doi.org/10.1016/j.mset.2018.12.006

2. Duchesne MA, Champagne S, Hughes RW (2017) Dry petroleum coke gasification in a pilot-scale entrained-flow gasifier and inorganic element partitioning model. Energ Fuel 31(7):6658-6669. https://doi.org/10.1021/acs.energyfuels.7b00111

3. Capson-Tojo G, Torres A, Munoz R, Bartacek J,. Jeison D (2017) Mesophilic and thermophilic anaerobic digestion of lipid-extracted microalgae N-gaditana for methane production Renew. Energ 105:539. DOI:10.1016/j.renene.2016.12.052. - 546, https://

4. Zhao C, Qiao XL, Cao Y, Shao QJ (2017) Application of hydrogen peroxide presoaking prior to ammonia fiber expansion pretreatment of energy crops. Fuel 205:184.

DOl:10.1016/j.fuel.2017.05.073. - 191, https://

5. Kings AJ, Raj RE, Miriam LRM, Visvanathan MA (2017) Growth studies on microalgae Euglena sanguinea in various natural eco-friendly composite media to optimize the lipid productivity. Biores Technol 244:1349-1357. https://doi.org/10.1016/j.biortech.2017.06.136

6. Song D, Fu J, Shi D (2008) Exploitation of oil-bearing microalgae for biodiesel. CJ of Biotechnol 24:341-348. https://doi.org/10.1016/S18722075(08)600163

7. Zhang Y, Kang X, Wang Z, Kong X, Li L, Sun Y, Zhu S, Feng S, Luo X, Lv P (2018) Enhancement of the energy yield from microalgae via enzymatic pretreatment and anaerobic codigestion. Energy 164:400-407. https://doi.org/10.1016/j.energy.2018.08.124

8. Mubarak M, Shaija A, Suchithra TV (2015) A review on the extraction of lipid from microalgae for biodiesel production. Algal Res 7:117-123. https://doi.org/10.1016/j.algal.2014.10.008

9. Halim R, Danquah MK, Webley PA (2012) Extraction of oil from microalgae for biodiesel production: A review. Biotechnol Adv 30:709-732. https://doi.org/10.1016/j.biotechadv.2012.01.001 
10. Surkatti R, Al-Zuhair S (2018) Effect of cresols treatment by microalgae on the cells composition. Journal of Water Process Engineering 26:250-256. DOI 10.1016/j.jwpe.2018.10.022.

11. Medina AR, Grima EM, Gimenez AG, Gonzalez MJ (1998) Downstream processing of algal polyunsaturated fatty acids. Biotechnol Adv 16:517-580. https://doi.org/10.1016/S07349750(97)00083-9

12. El-Naas MH, Surkatti R, Al-Zuhair S S (2016) Petroleum refinery wastewater treatment: a pilot scale study. Journal of Water Process Engineering 14:71. DOI:10.1016/j.jwpe.2016.10.005 - 76, https://

13. Pragya N, Pandey KK, Sahoo PK (2013) A review on harvesting, oil extraction and biofuels production technologies from microalgae. Renew Sustain Ener Reviw 24:159-171.

https://doi.org/10.1016/j.rser.2013.03.034

14. Iverson SJ, Lang SL, Cooper MH (2011) Comparison of the Bligh and Dyer and Folch methods for total lipid determination in a broad range of marine tissue. Lipids 36 (11): 1283-1287. https://doi: 10.1007/s11745-001-0843-0

15. Kadir WNA, Lam MK, Uemura Y, Lim JW, Lee KT (2018) Harvesting and pre-treatment of microalgae cultivated in wastewater for biodiesel production: A review. Energy Convers Manag 171:1416-1429. https://doi.org/10.1016/j.enconman.2018.06.074

16. Bligh EG, Dyer WJ (1959) A rapid method of total lipid extraction and purification. Canadian J of Biochemistry Physiology 37:911-917. https://doi.org/10.1139/y59-099

17. Dejoye C, Vian MA, Lumia G, Bouscarle C, Charton F, Chemat F (2011) Combined extraction processes of lipid from Chlorella vulgaris microalgae: microwave prior to supercritical carbon dioxide extraction. Int J Mol Sci 12:9332-9341. doi 10.3390/ijms12129332.

18. Wang L, Weller CL (2006) Recent advances in extraction of nutraceuticals from plants. Trends in Food Science Technol 17:300-302. https://doi.org/10.1016/j.tifs.2005.12.004

19. Surendhiran D, Vijay M (2014) Effect of various pretreatment for extracting intracellular lipid from Nannochloropsis oculata under nitrogen replete and depleted conditions. ISRN Chemical Engineering 2014. 2014

20. Kumar SJ, Kumar GV, Dash A, Scholz P, Banerjee R (2017) Sustainable green solvents and techniques for lipid extraction from microalgae: A review. Algal Res 1:138-147. https://doi.org/10.1016/j.algal.2016.11.014

21. Al-Ameri M, Al-Zuhair S (2018) Using Switchable Solvents for Enhanced, Simultaneous Microalgae Oil Extraction-Reaction for Biodiesel Production. Biochem Eng J 141: 217-224. https://doi.org/10.1016/j.bej. 2018.10.017

22. Couto RM, Simões PC, Reis A, Da Silva TL, Martins VH, Vicente YS (2010) Supercritical fluid extraction of lipids from the heterotrophic microalga Crypthecodinium cohnii. Engineering in Life Sciences 10 (2010) 158-164. https://doi.org/10.1002/elsc.200900074

23. Chen B, Wan C, Mehmood MA, Chang JS, Bai F, Zhao X (2017) Manipulating environmental stresses and stress tolerance of microalgae for enhanced production of lipids and value-added products-a review (Part2). Bioresour Technol 244:1198-1206. doi 10.1016/j.biortech.2017.05.170. 
24. Beer LL, Boyd ES, Peters JW, Posewitz MC (2009) Engineering algae for biohydrogen and biofuel production. Curr Opin Biotechnol 20:264-271. https://doi:10.1016/j.copbio.2009.06.002

25. Wágner DS, Valverde-Pérez B, Plósz BG (2018) Light attenuation in photobioreactors and algal pigmentation under different growth conditions - model identification and complexity assessment. Algal Res 35:488-499. https://doi.org/10.1016/j.algal.2018.08.019

26. Laamanen CA, Ross GM, Scott JA (2016) Flotation harvesting of microalgae. Renew Sustain Energy Rev 58:75-86. https://doi.org/10.1016/j.rser.2015.12.293

27. Goh BHH, Ong HC, Cheah MY, Chen WH, Yu KL, Mahlia TMI (2019) Sustainability of direct biodiesel synthesis from microalgae biomass: A critical review. Renew Sustain Ener Rev 107: 59-74. https://doi.org/10.1016/j.rser. 2019.02.012

28. Lu D, Liu X, Apul OG, Zhang L, Ryan DK, Zhang X (2019) Optimization of biomethane production from anaerobic Co-digestion of microalgae and septic tank sludge. Biomass Bioenerg 127:105266. https://doi:10.1016/j.biombioe.2019.105266

29. Xiao C, Liao Q, Fu Q, Huangc Y, Chen YH, Zhang H, Xia A, Zhu X, Reungsang A, Liu Z (2019) A solardriven continuous hydrothermal pretreatment system for biomethane production from microalgae biomass. Appl Energy 236:1011-1018. https://doi.org/10.1016/j.apenergy.2018.12.014

30. Hossain N, Zaini J, Mahlia TMI (2019) Life cycle assessment, energy balance and sensitivity analysis of bioethanol production from microalgae in a tropical country. Renew Sustain Ener Rev 115:109371. https://doi.org/10.1016/j.rser.2019.109371

31. Phwan CK, Ong HC, Chen WH, Ling TC, Ng EP, Show PL PL (2018) Overview: Comparison of pretreatment technologies and fermentation processes of bioethanol from microalgae. Energy Convers Manag 173:81-94. https://doi.org/10.1016/j.enconman.2018.07.054

32. Arabi M, Yaghoubi S, Tajik JJ (2019) A mathematical model for microalgae-based biobutanol supply chain network design under harvesting and drying uncertainties. Energy 179:1004-1016. https://doi.org/10.1016/j.energy.2019.04.219

33. Yeong TK, Jiao K, Zeng X, Lin L, Pan S, Danquah M (2018) Microalgae for biobutanol production Technology evaluation and value Proposition. Algal Res 31:367-376. https://doi.org/10.1016/j.algal.2018.02.029

34. Schüler LM, Schulze PSC, Pereira H, Barreira L, Leon R, Varela J (2017) Trends and strategies to enhance triacylglycerols and high-value compounds in microalgae. Algal Research 25 (Sup C): 263273. https://doi.org/10.1016/j.algal.2017.05.025

35. Goto M, Kanda H, Wahyudiono, Machmudah S (2015) Extraction of carotenoids and lipids from algae by supercritical $\mathrm{CO}_{2}$ and subcritical dimethyl ether. J Supercritical Fluids 96:245-251. https://doi.org/10.1016/j.supflu.2014.10.003

36. Yang F, Xiang W, Sun X, Wu H, Li T, Long L (2014) A novel lipid extraction method from wet microalga Picochlorum sp. at room temperature., Mar. Drugs 12: 1258. https://doi:10.3390/md12031258

37. Miriam LRM, Raj RE, Kings AJ, Visvanathan MA (2017) Identification and characterization of a novel biodiesel producing halophilic Aphanothece halophytica and its growth and lipid optimization in 
various media. Energy Convers Manag 141:93-100.

https://doi.org/10.1016/j.enconman.2016.05.041

38. Niels H, Ingolf P, Frank B (2012) Biomass productivity and productivity of fatty acids and amino acids of microalgae strains as key characteristics of suitability for biodiesel production. $\mathrm{J}$ of Appl Phycology 24:1407-1418. https://doi:10.1007/s10811-012-9795-3

39. Siham D, Djamal Z, Luveshan R, Ismail R, Faizal B (2016) Cultivation of Chlorella pyrenoidosa in outdoor open raceway pond using domestic wastewater as medium in arid desert region. Bioresour Technol 219:749-752. https://doi.org/10.1016/j.biortech.2016.08.019

40. Suparmaniam U, Lam MK, Uemura Y, Lim JW, Lee KT, Shuit SH (2019) Insights into the microalgae cultivation technology and harvesting process for biofuel production: A review. Renew Sustain Energy Rev 115:109361. https://doi.org/10.1016/j.rser.2019.109361

41. Zhang Q, Li X, Guo D, Ye T, Xiong M, Zhu L, Liu C, Jin S, Hu Z (2018) Operation of a vertical algal biofilm enhanced raceway pond for nutrient removal and microalgaebased by-products production under different wastewater loadings. Bioresour Technol 253:323-332.

https://doi.org/10.1016/j.biortech.2018.01.014

42. Maza-Márquez P, González-Martínez A, Rodelas B, González-López J J (2017) Full scale photobioreactor for biotreatment of olive washing water: structure and diversity of the microalgaebacteria consortium. Bioresour Technol 238:389-398.

https://doi.org/10.1016/j.biortech.2017.04.048

43. Chokshi K, Pancha I, Ghosh A, Mishra S (2017) Salinity induced oxidative stress alters the physiological responses and improves the biofuel potential of green microalgae Acutodesmus dimorphus. Bioresour Technol 244:1376-1383. https://doi.org/10.1016/j.biortech.2017.05.003

44. Chen B, Wan C, Mehmood MA, Chang JS, Bai F, Zhao X (2017) Manipulating environmental stresses and stress tolerance of microalgae for enhanced production of lipids and value-added products: A review. Bioresour Technol 244:1198-1206. https://doi.org/10.1016/j.biortech.2017.05.170

45. Enamala MK, Enamala S, Chavali M, Donepudi J, Yadavalli R, Kolapalli B, Aradhyula TV, Velpuri J, Kuppam C (2018) Production of biofuels from microalgae - A review on cultivation, harvesting, lipid extraction and numerous applications of microalgae. Renew Sust Energ Rev 94:49-68. https://doi.org/10.1016/j.rser.2018.05.012

46. Yin Z, Zhu L, Li S, Hu T, Chu R, Mo F, Hu D, Liu C, Li B (2020) A comprehensive review on cultivation and harvesting of microalgae for biodiesel production: Environmental pollution control and future directions. Biores Technol 301:122804. https://doi.org/10.1016/j.biortech.2020.122804

47. Kumar AV, Agila E, Sivakumar P, Salam Z, Rengasmy R, Ani FN (2014) Optimization and characterization of biodiesel production from microalgae Botryococcus grown at semi-continuous system. Energy Convers Manag 88:936-946. https://doi.org/10.1016/j.enconman.2014.09.019

48. Rashid N, Rehman MSW, Sadiq M, Mahmood T, Han JI (2014) Current status, issues and developments in microalgae derived biodiesel production. Renew Sustain Ener Rev 40:760-778. https://doi.org/10.1016/j.rser.2014.07.104 
49. Letelier-Gordo CO, Holdt SL, De-Francisci D, Karakashev DB, Angelidaki I (2014) Effective harvesting of the microalgae Chlorella protothecoides via bioflocculation with cationic starch. Bioresour Technol 167:214-218. https://doi.org/10.1016/j.biortech.2014.06.014

50. Dharma S, Masjuki HH, Ong HC, Sebayang AH, Silitonga AS, Kusumo F, Mahlia TMI (2016) Optimization of biodiesel production process for mixed Jatropha curcas - Ceiba pentandra biodiesel using response surface methodology. Ener Conv Manage 115:178-190. https://doi.org/10.1016/j.enconman.2016.02.034

51. Taher H, Al-Zuhair S, Al-Marzouqi AH, Haik Y, Farid M (2014) Effective extraction of microalgae lipids from wet biomass for biodiesel production. Biomass Bioenerg 66:159-167. https://doi.org/10.1016/j.biombioe.2014.02.034

52. Lakshmikandan M, Murugesan AG, Wang S, Abomohra AEF, Jovita PA, Kiruthiga S (2019) Sustainable biomass production under $\mathrm{CO}_{2}$ conditions and effective wet microalgae lipid extraction for biodiesel production. J Clean Prod 247:119398. https://doi.org/10.1016/j.jclepro.2019.119398

53. Chen J, Li J, Dong W, Zhang X, Tyagi RD, Drogui P, Surampalli RY (2018) The potential of microalgae in biodiesel production. Renew Sustain Energy Rev 90:336-346. https://doi.org/10.1016/j.rser.2017.07.044

54. Gude PD, Mannarswamy VG, Deng A, Cooke S, Munson-McGee P, Rhodes SI, Lammers P, Nirmalakhandan N (2011) Optimization of direct conversion of wet algae to biodiesel under supercritical methanol conditions. Biores Technol 102:118-122.

https://doi.org/10.1016/j.biortech.2010.06.031

55. Liu Z, Rochfort S, Cocks BG (2016) Optimization of a single phase method for lipid extraction from milk. J Chromatogr A 1458:145-149. https://doi.org/10.1016/j.chroma.2016.06.055

56. Hosseini NS, Shang H, Scott JA (2018) Optimization of microalgae sourced lipids production for biodiesel in a top-lit gas-lift bioreactor using response surface methodology. Energy 146:47-56. https://doi.org/10.1016/j.energy.2017.08.085

57. Kadi H, Fellag H (2001) Modelling of oil extraction from olive foot cake using hexane. Grasas Aceites 52:369-372. https://doi:10.3989/gya.2001.v52.i6.346

58. Pokoo-Aikins G, Heath A, Mentzer RA, Mannan SM, Rogers WJ, El-Halwagi MM (2010) A multi-criteria approach to screening alternatives for converting sewage sludge to biodiesel. J Loss Prev Process Ind 23:412-420. https://doi:10.1016/j.jlp.2010.01.005

59. Zhang L, Cheng J, Pei H, Pan JL, Hou Q, Han F (2018) Cultivation of microalgae using anaerobically digested effluent from kitchen waste as a nutrient source for biodiesel production. Renewable Energy 115:276-287. https://doi.org/10.1016/j.renene.2017.08.034

60. Jesus SSD, Ferreira GF, Moreira LS, Maciel MRW, Filho RM (2019) Comparison of several methods for effective lipid extraction from wet microalgae using green solvents. Renew Ener 43:130-141. https://doi.org/10.1016/j.renene.2019.04.168

61. Patil PD, Gude VG, Mannarswamy A, Deng S, Cooke P, Munson-McGee S, Rhodes I, Lammers P, Nirmalakhandan N (2011) Optimization of direct conversion of wet algae to biodiesel under 
supercritical methanol conditions. Biores Technol 102:118-122.

https://doi.org/10.1016/j.biortech.2010.06.031

62. Zhou X, Jin W, Wang Q, Guo S, Tu R, Han S, Chen C, Xie G, Qu F, Wang Q (2019) Enhancement of productivity of Chlorella pyrenoidosa lipids for biodiesel using co-culture with ammonia-oxidizing bacteria in municipal wastewater. Renewable Energy 151:598-603.

https://doi.org/10.1016/j.renene.2019.11.063

63. Lee SJ, Yoon BD, Oh HM (1998) Rapid method for the determination of lipid from the green alga Botryococcus braunii. Biotechnol Tech 12:553-556. https://doi.org/10.1023/A:1008811716448

64. Rajak U, Nashine P, Verma TN (2018) Assessment ofdiesel engine performance using spirulina microalgae biodiesel. Energy 166:1025-1036. https://doi.org/10.1016/j.energy.2018.10.098

65. Ashokkumar V, Agila E, Sivakumar P, Salam Z, Rengasmy R, Ani FN (2014) Optimization and characterization of biodiesel production from microalgae Botryococcus grown at semi-continuous system. Energy Convers Manage 88:936-946. https://doi.org/10.1016/j.enconman.2014.09.019

66. Pullen J, Saeed K (2014) Experimental study of the factors affecting the oxidation stability of biodiesel FAME fuel. Fuel Processing Technology 125: 223-235. https://doi.org/10.1016/j.fuproc.2014.03.032

67. Betiku E, Omilakin OR, Ajala SO, Okeleye AA, Taiwo AE, Solomon BO (2014) Mathematical modelling and process parameters optimization studies by artificial neural network and response surface methodology: a case of nonedible neem (Azadirachta indica) seed oil biodiesel synthesis. Energy 72:266-273. https://doi.org/10.1016/j.energy.2014.05.033

68. Shekh AY, Shrivastava P, Gupta A, Krishnamurthi K, Devi SS, Mudliar SN (2016) Biomass and lipid enhancement in Chlorella sp. with emphasis on biodiesel quality assessment through detailed FAME signature. Biores Technol 201:276-286. https://doi.org/10.1016/j.biortech.2015.11.058

69. Miriam LRM, Raj RE, Kings AJ, Visvanathan MA (2017) Enhanced FAME production using green catalyst with superior profile from the isolated halophilic Aphanothece halophytica grown in raceway ponds. Energy Convers Manag 151:63-72. https://doi.org/10.1016/j.enconman.2017.08.071

70. Anahas AMP, Muralitharan G (2015) Isolation and screening of heterocystous cyanobacterial strains for biodiesel production by evaluating the fuel properties from fatty acid methyl ester (FAME) profiles. Biores Technol 184:9-17. https://doi.org/10.1016/j.biortech.2014.11.003

71. Kings AJ, Raj RE, Miriam LRM, Visvanathan MA (2017) Cultivation, extraction and optimization of biodiesel production from potential microalgae Euglena sanguinea using eco-friendly natural catalyst. Energy Convers Manag 141:224-235. https://doi.org/10.1016/j.enconman.2016.08.018

72. Lani NS, Ngadi N, Yahya NY, Rahman RA (2017) Synthesis, characterization and performance of silica impregnated calcium oxide as heterogeneous catalyst in biodiesel production. J Clean Prod 146:116-124. https://doi.org/10.1016/j.jclepro.2016.06.058

73. Glisic SB, Pajnik JM, Orlovic AM (2016) Process and techno-economic analysis of green diesel production from waste vegetable oil and the comparison with ester type biodiesel production. Appl Energy 170:176-185. https://doi.org/10.1016/j.apenergy.2016.02.102 


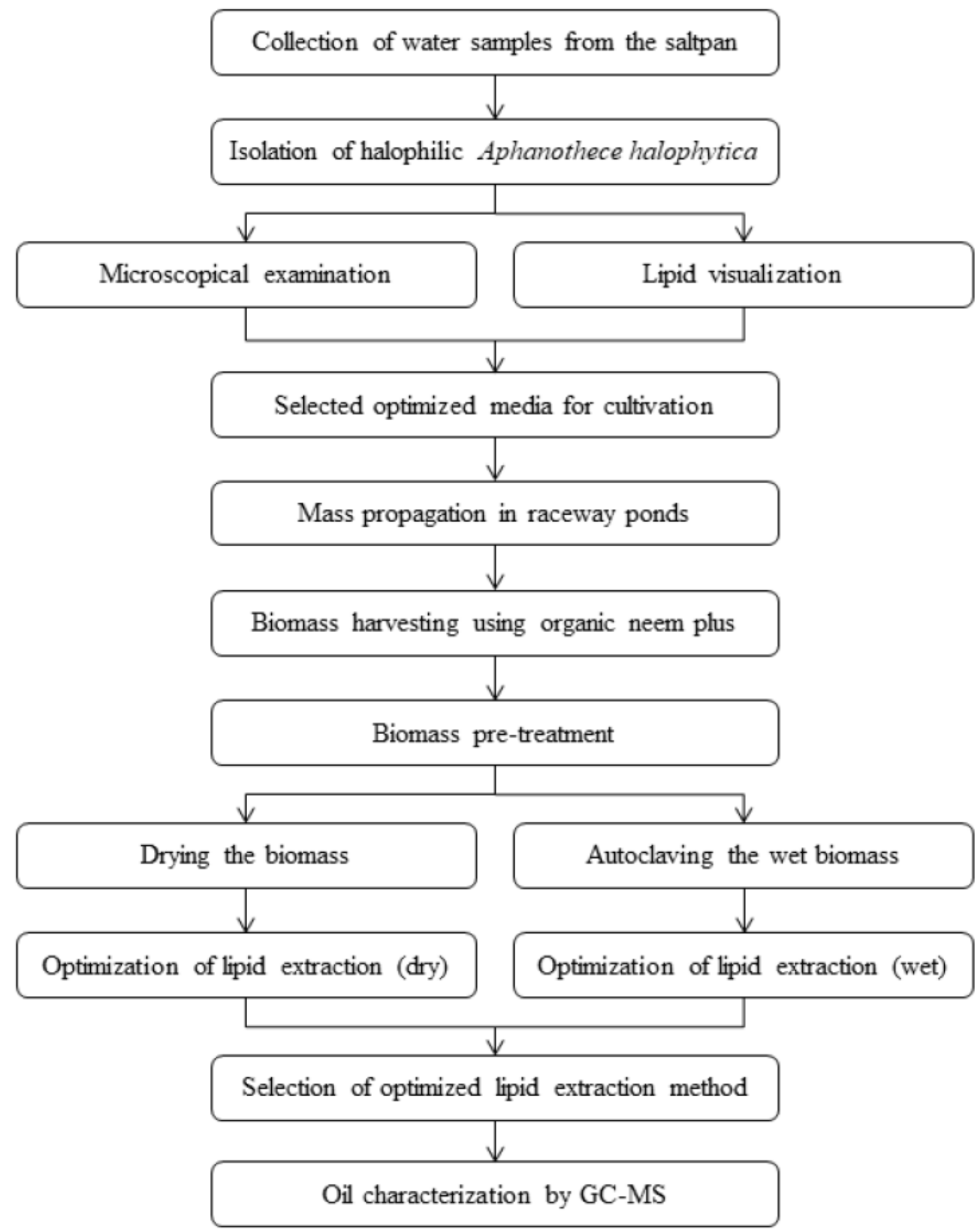

Figure 1

Methodology of the lipid extraction process from the microalgal strain 


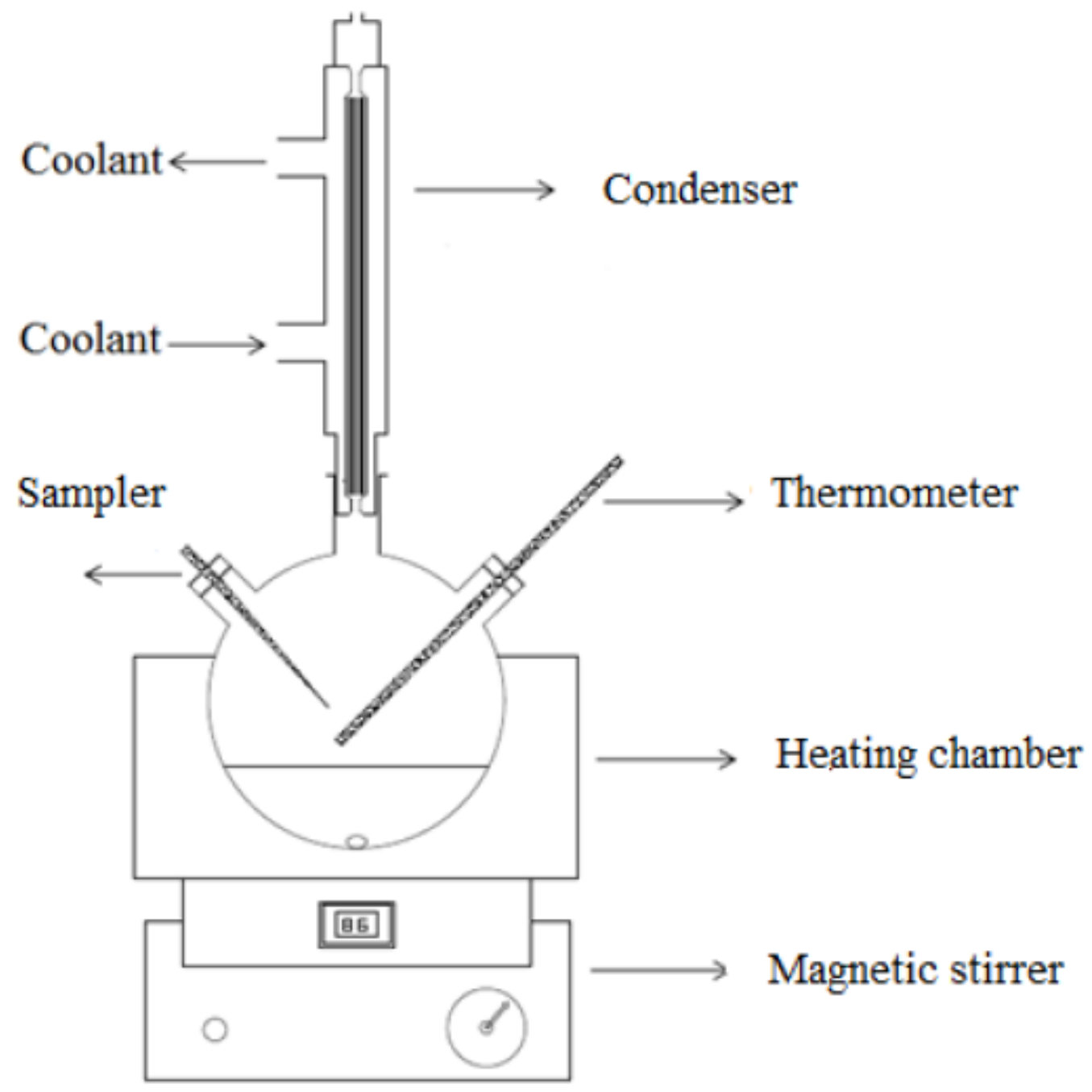

Figure 2

Block diagram of the batch mode lipid extraction setup 


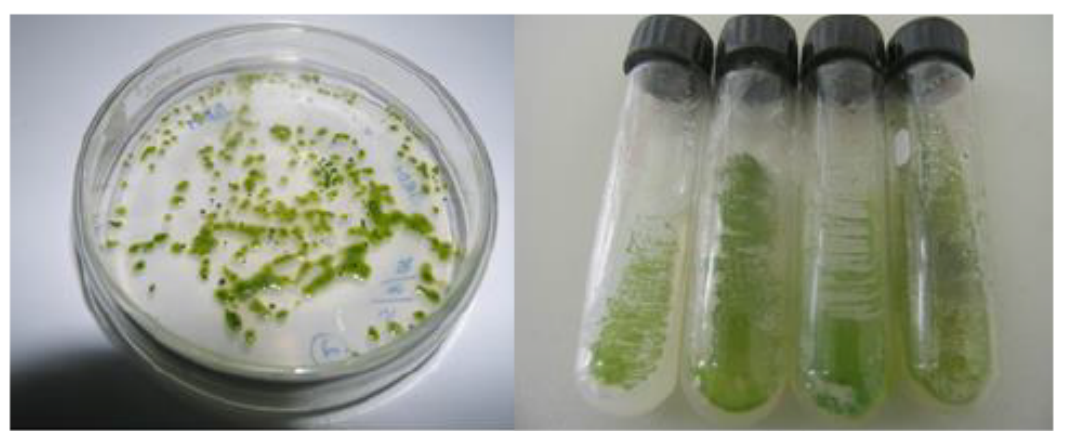

Stock culture

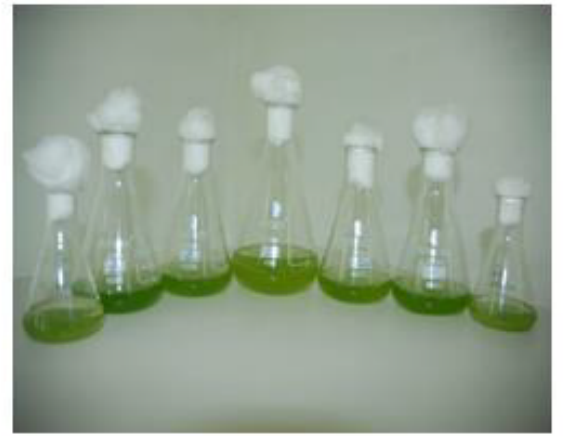

Flask culture

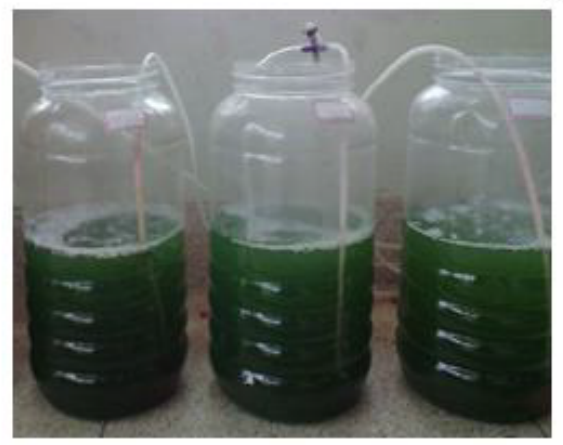

Jar culture

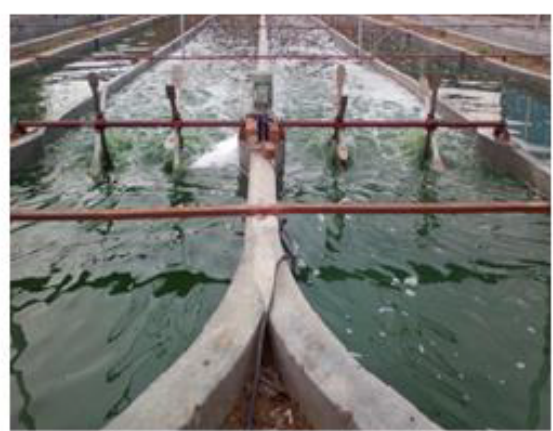

仓 Raceway pond culture

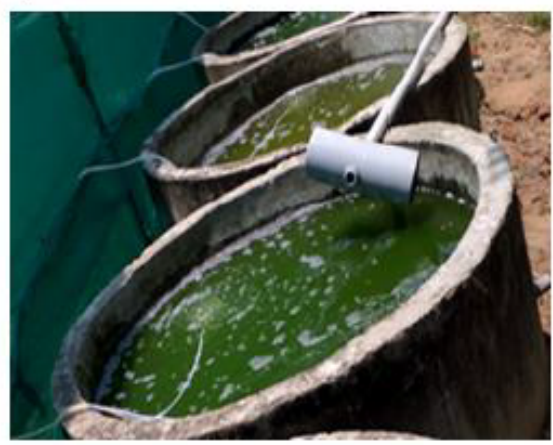

仓 Round tank culture

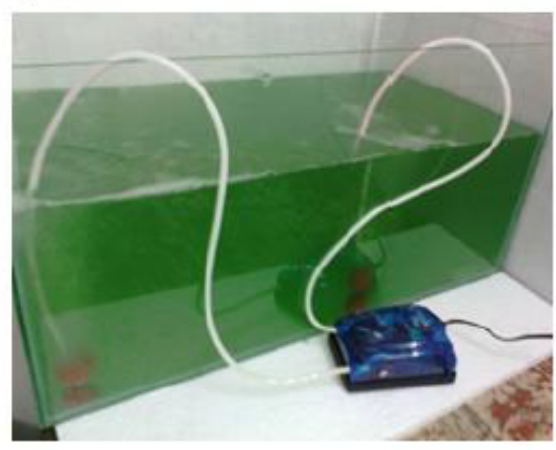

Glass tank culture

Figure 3

Mass propagation of microalgae from basic culture to raceway ponds 


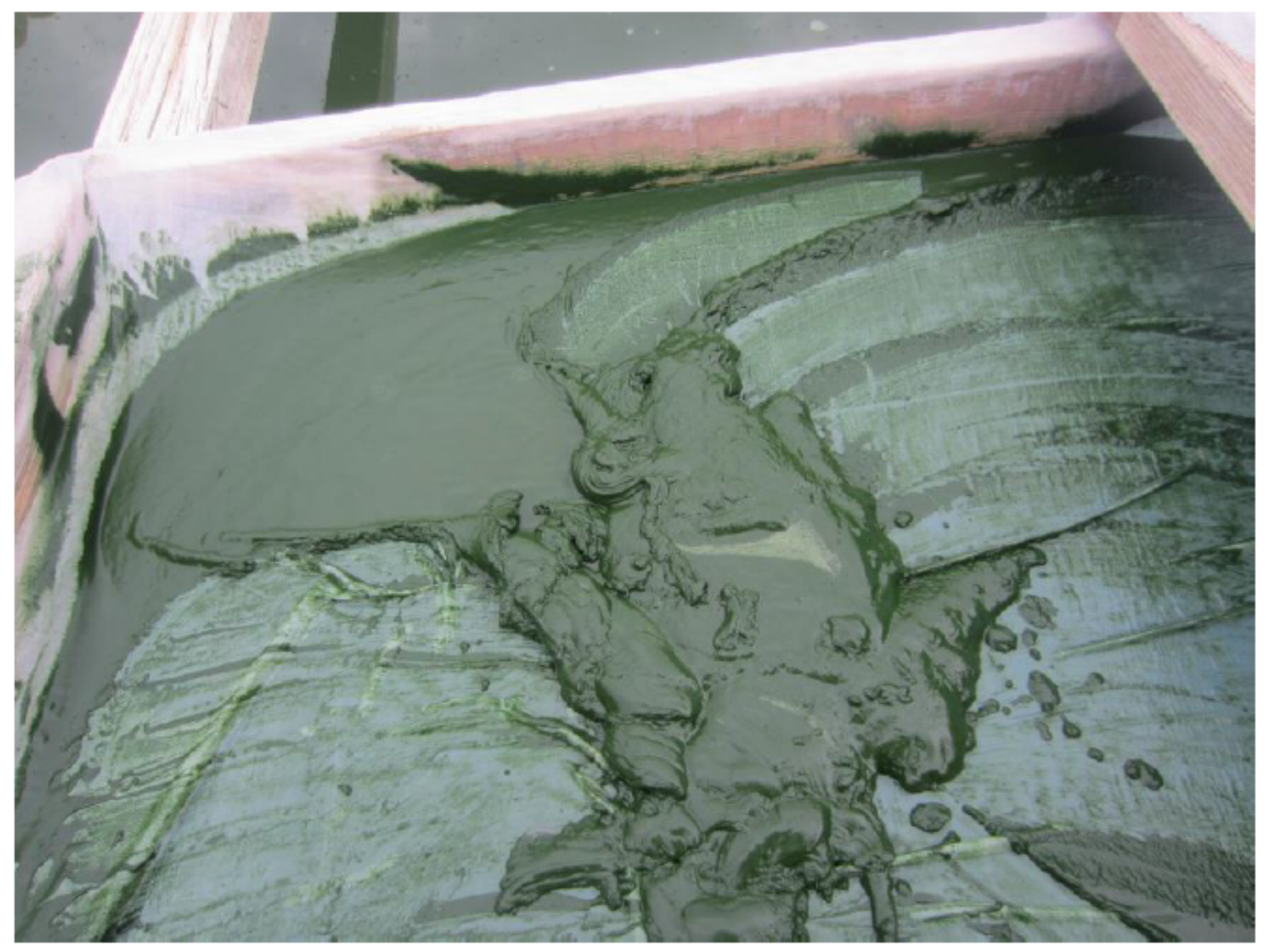

Figure 4

Harvested wet biomass for lipid extraction 


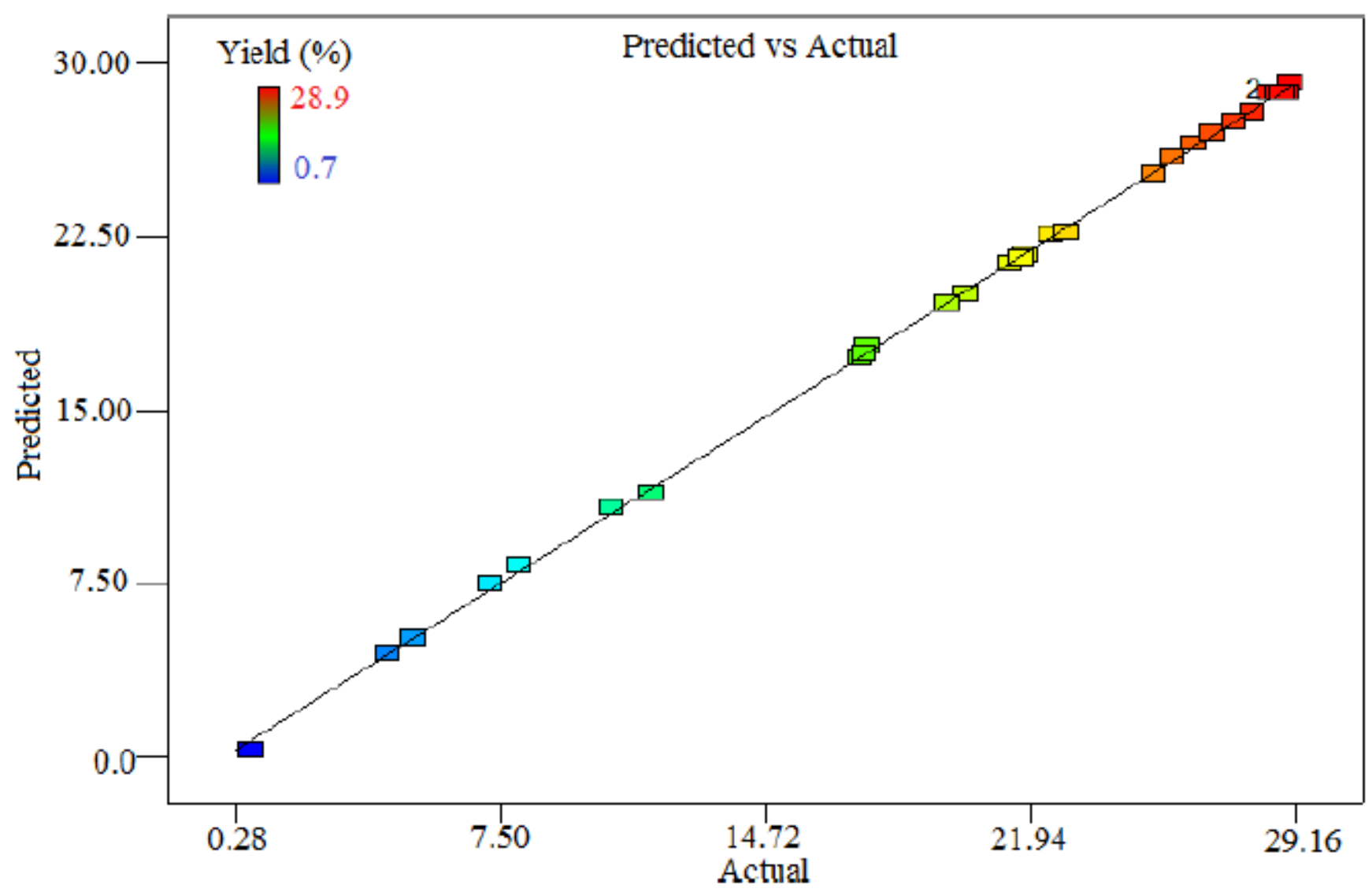

Figure 5

The plot of lipid yield by prediction vs actual yield for wet biomass 


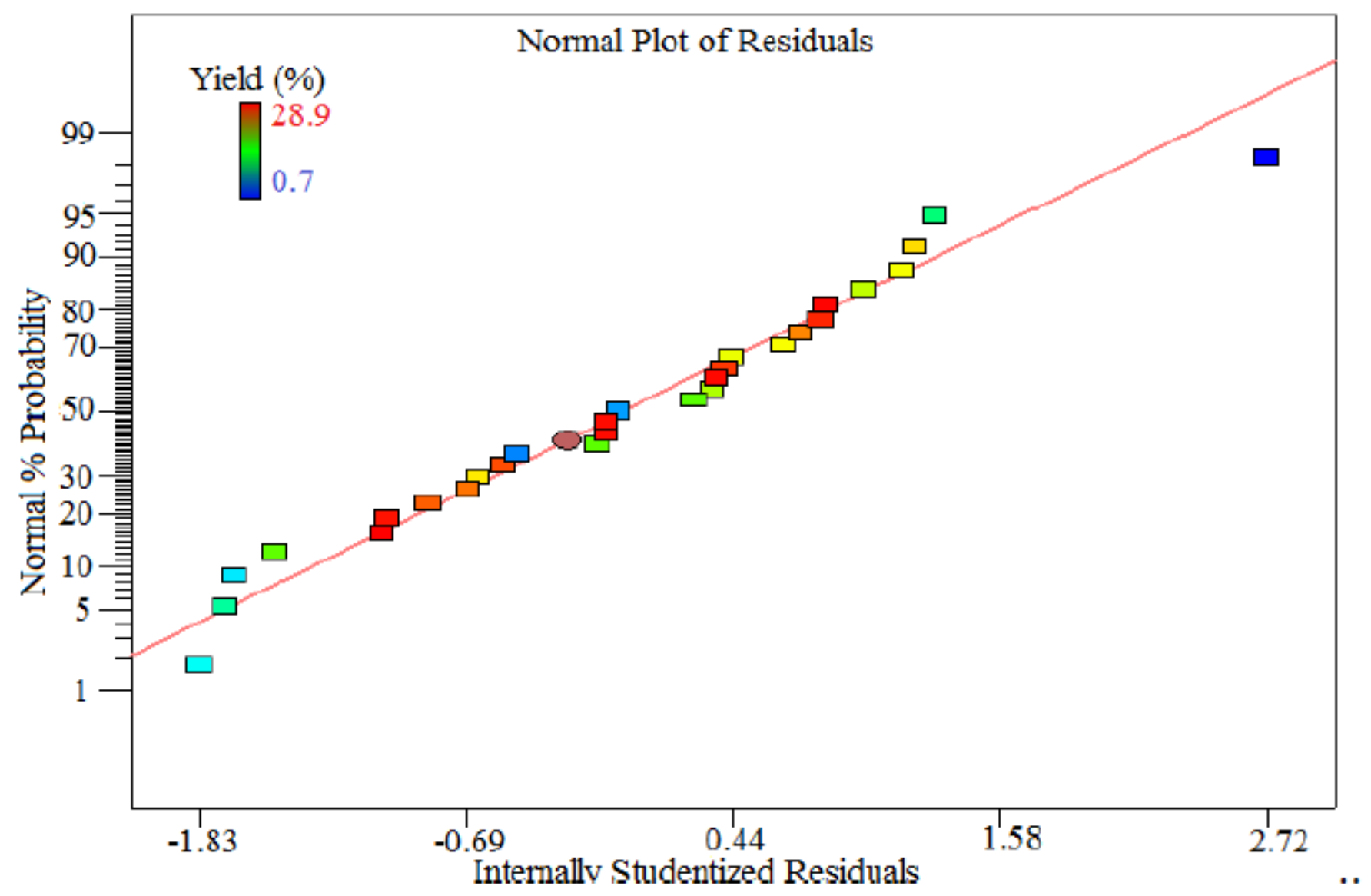

Figure 6

Normal probability plot of the residuals of the developed model to optimize the lipid extraction process on wet biomass basis 


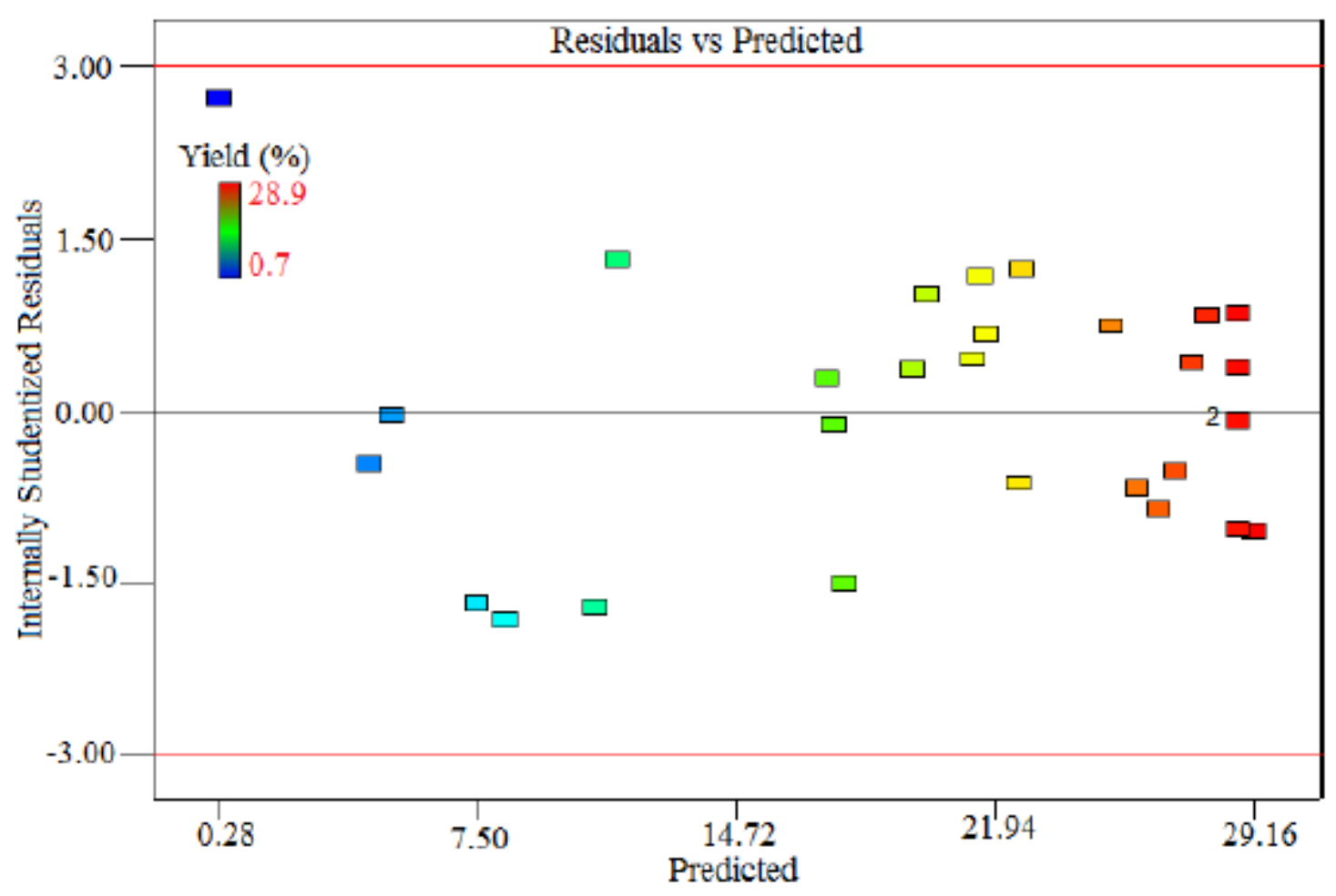

Figure 7

Plot of residual vs predicted response of the model to optimize the lipid extraction process on wet basis 


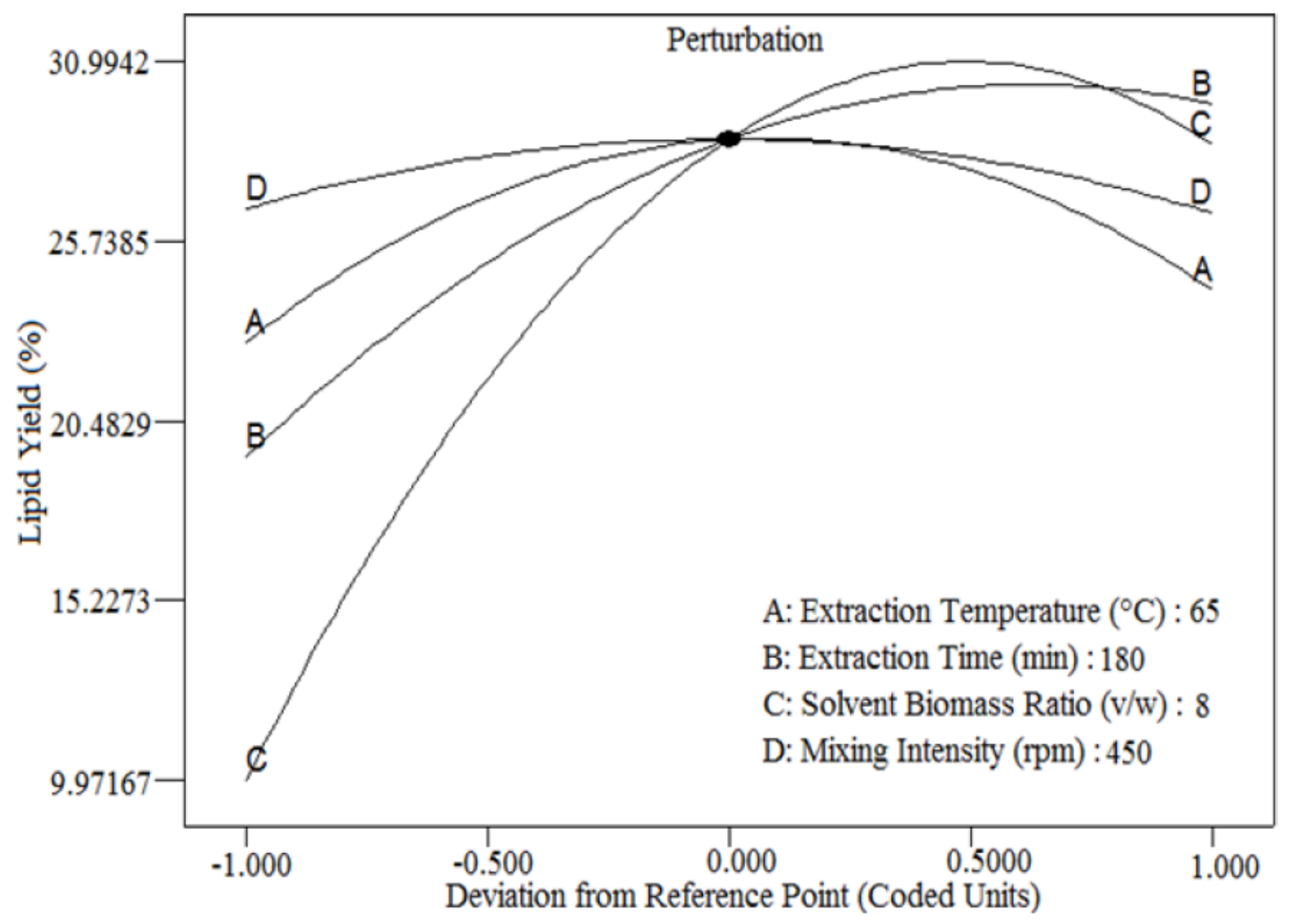

Figure 8

Perturbation chart to attain the influences of the lipid extraction process parameters on wet basis 


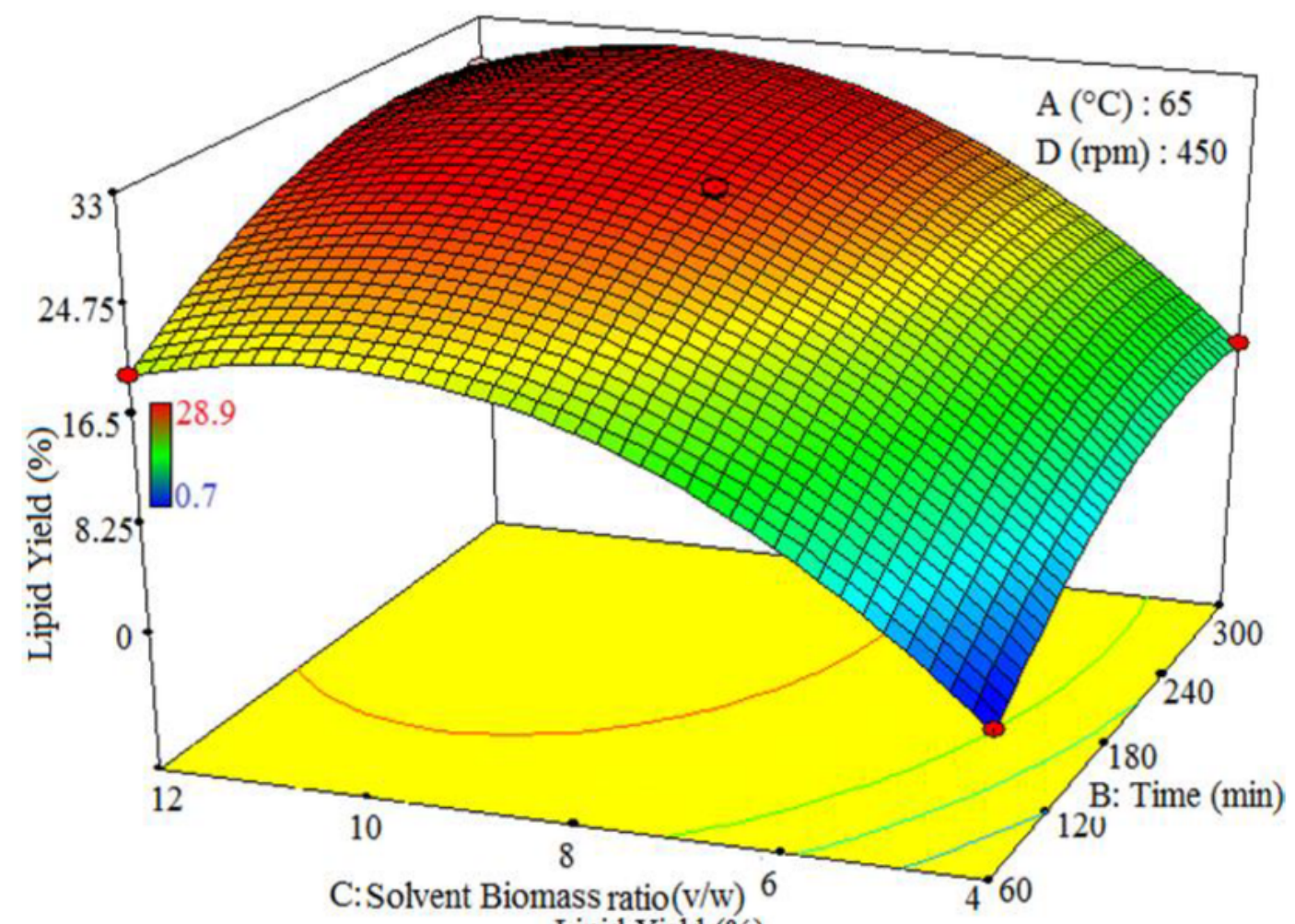

Lipid Yield (\%)

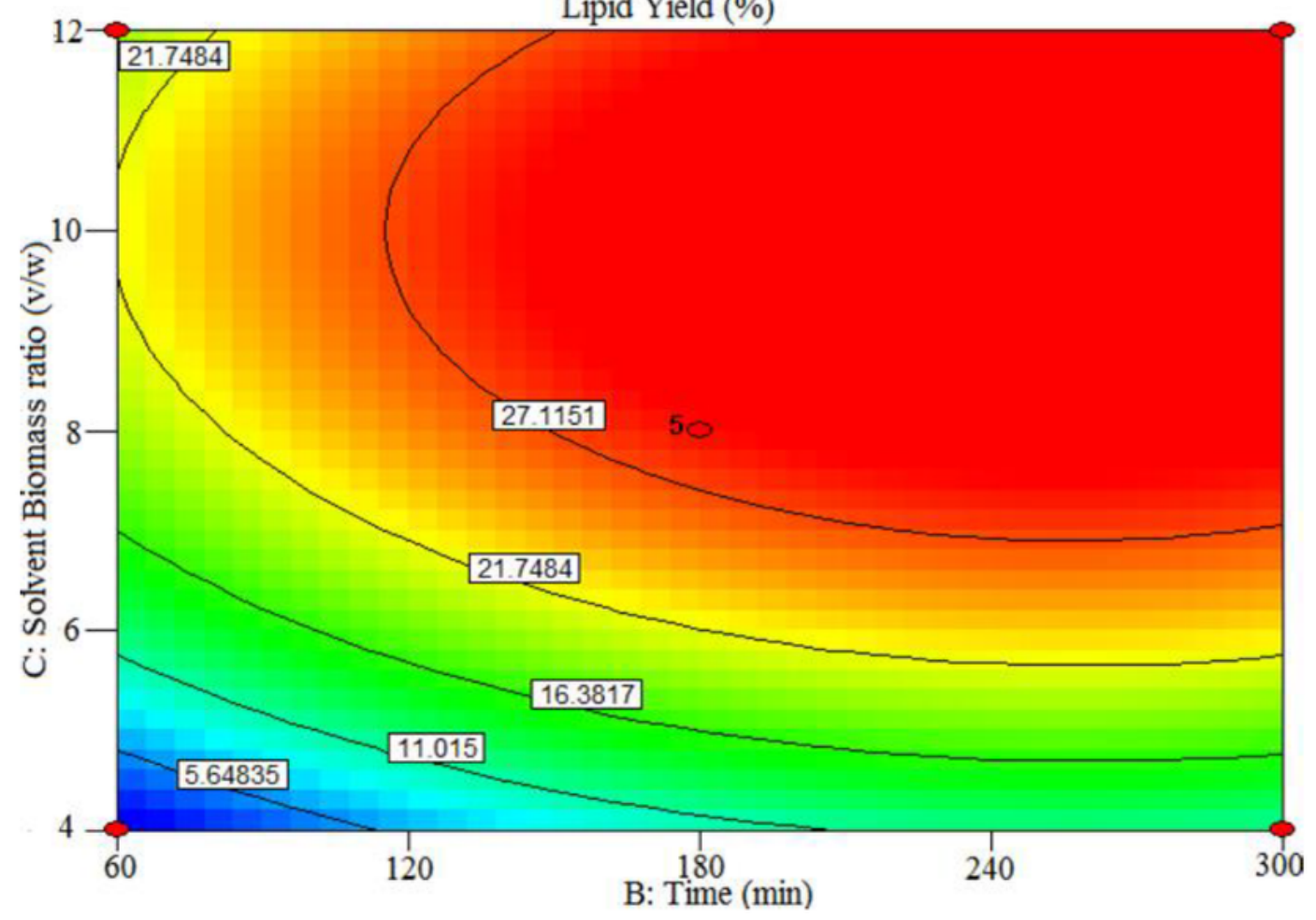

\section{Figure 9}

The 3D and contour plot of solvent biomass ratio and reaction time from the empirical model for maximizing the lipid yield from wet biomass 

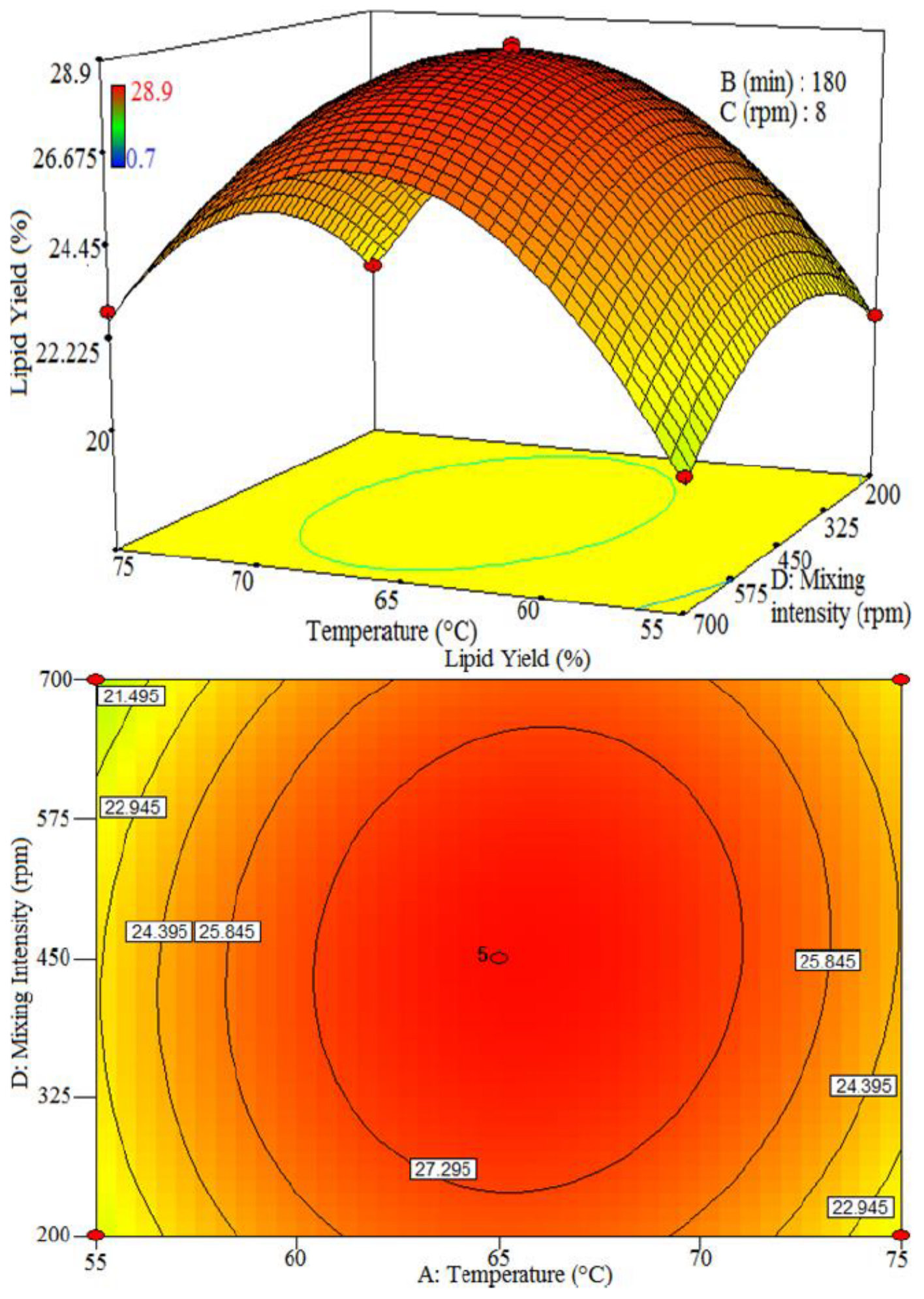

Figure 10

The 3D and contour plot of temperature and mixing intensity time from the empirical model for maximizing the lipid yield from wet biomass 


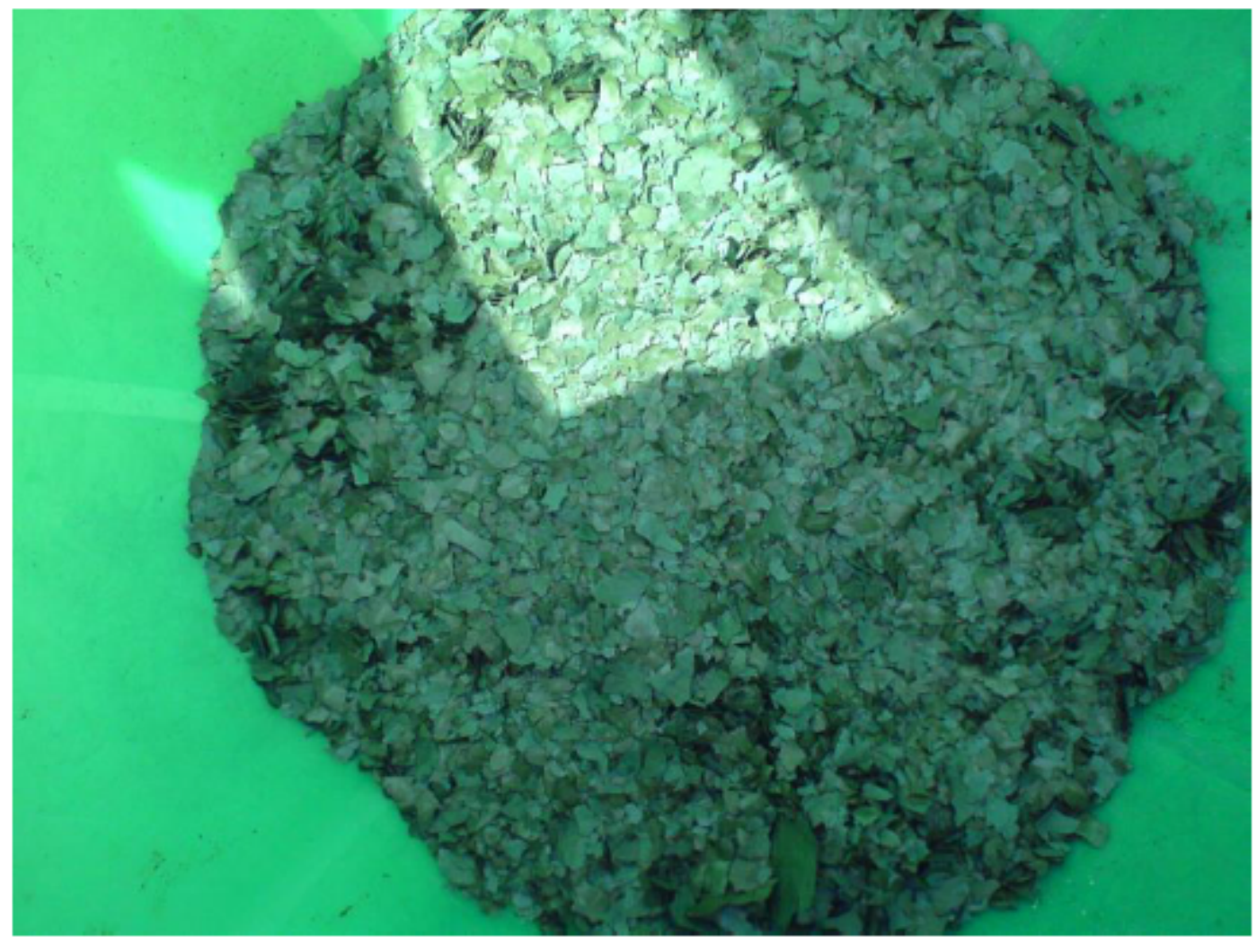

Figure 11

Harvested dried biomass for lipid extraction 


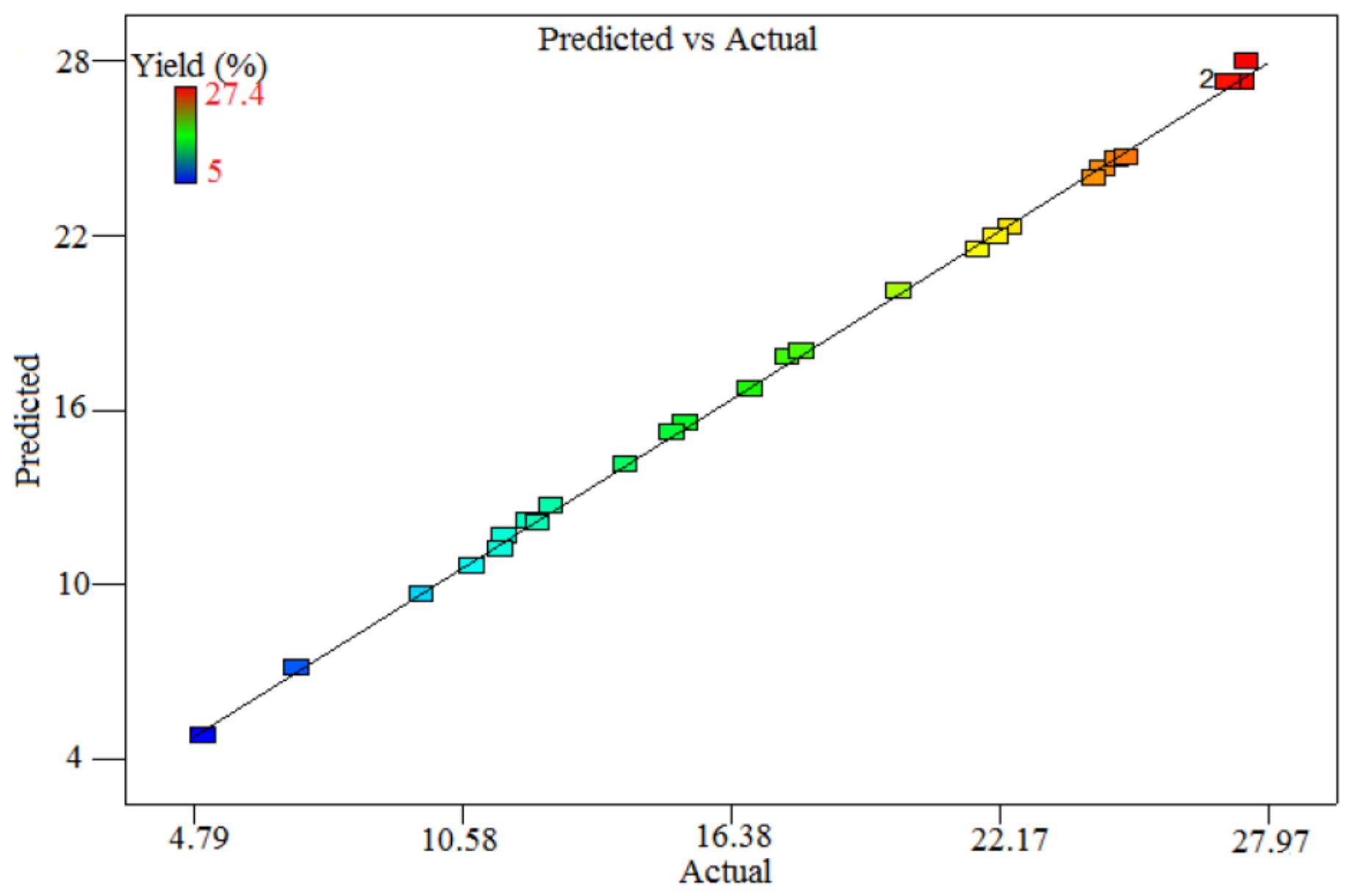

Figure 12

The plot of lipid yield by prediction vs actual yield for drybiomass 


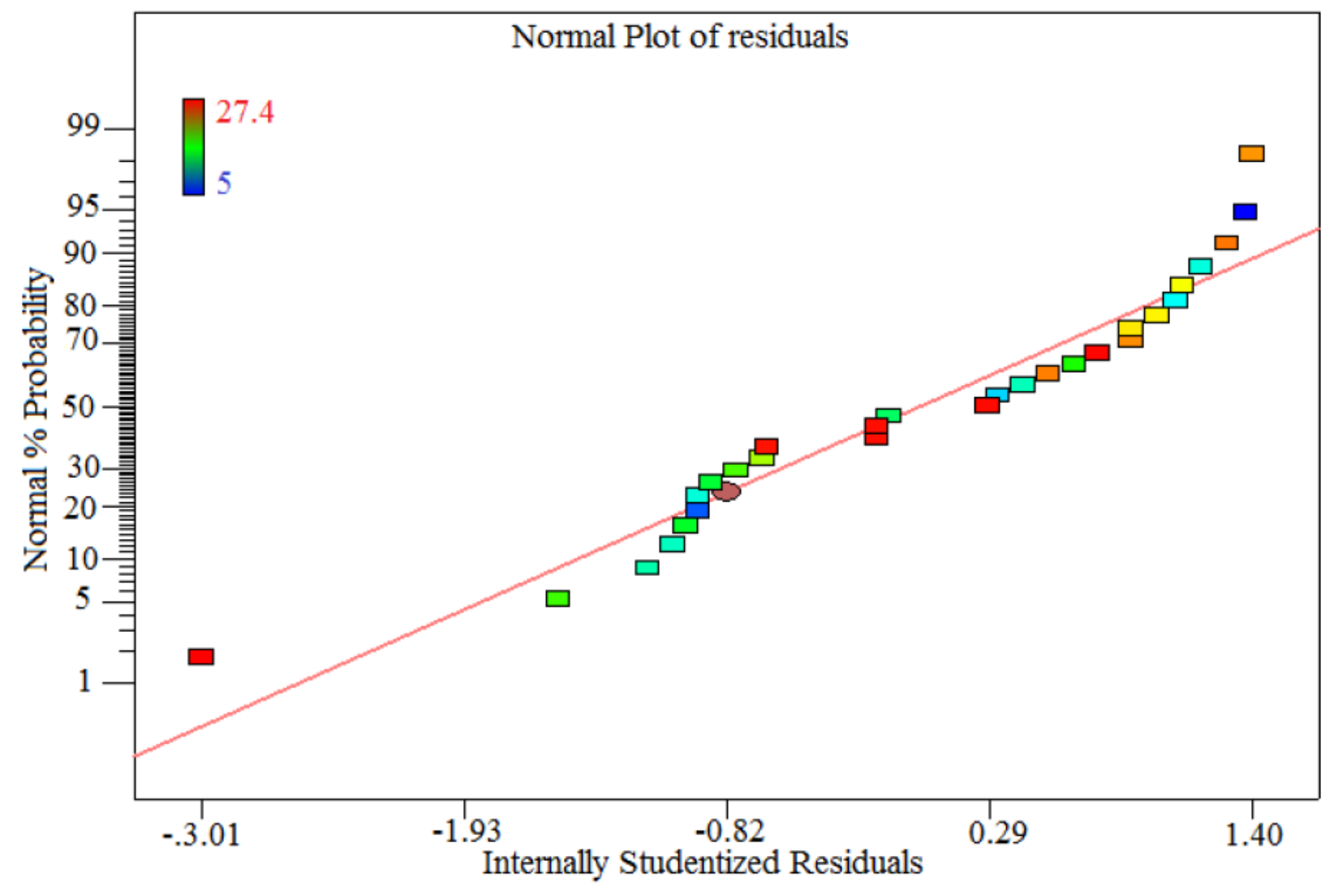

Figure 13

Normal probability plot of the residuals of the developed model to optimize the lipid extraction process on dry biomass basis 


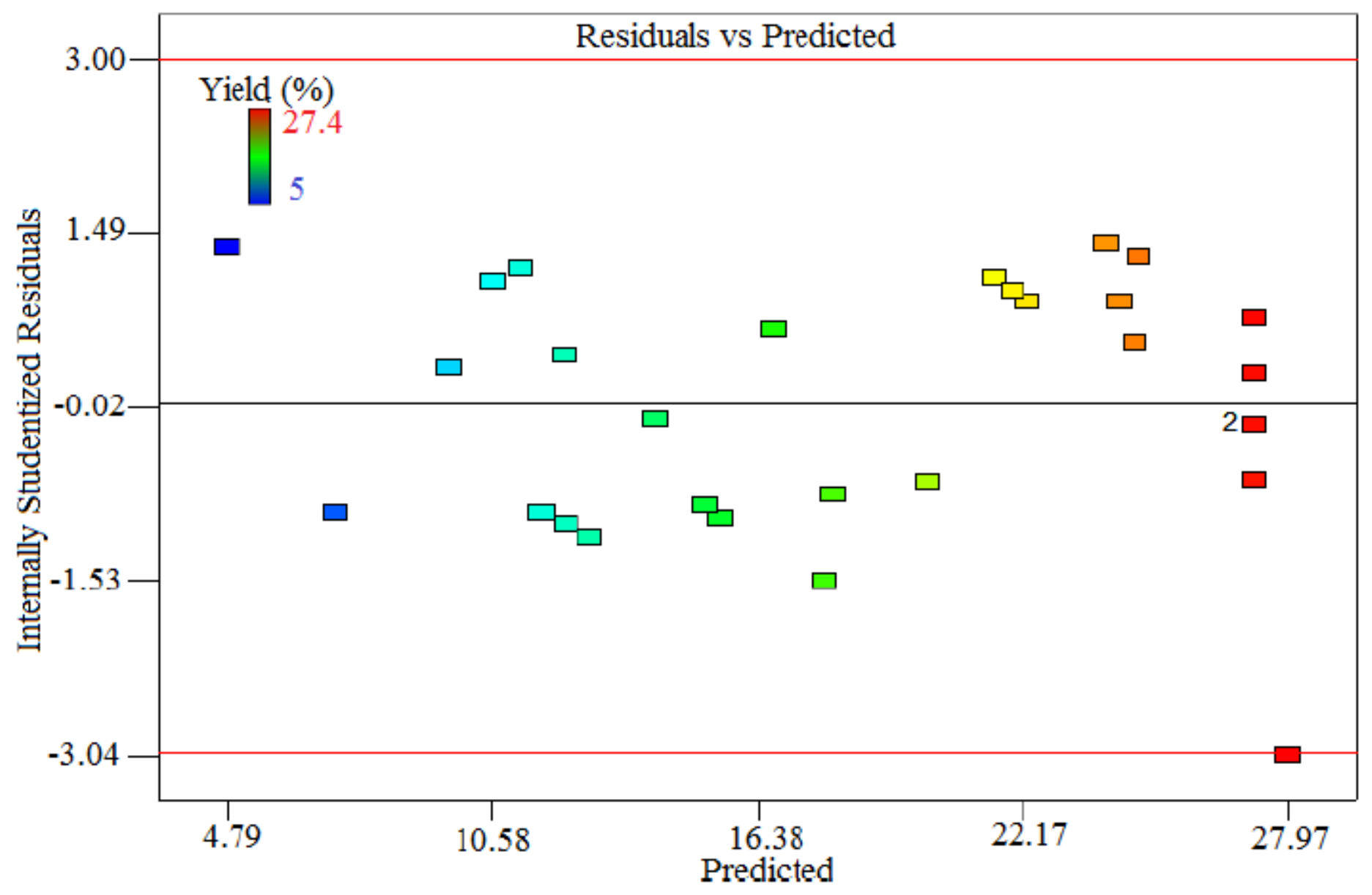

Figure 14

Plot of residual vs predicted response of the model to optimize the lipid extraction process on dry basis 


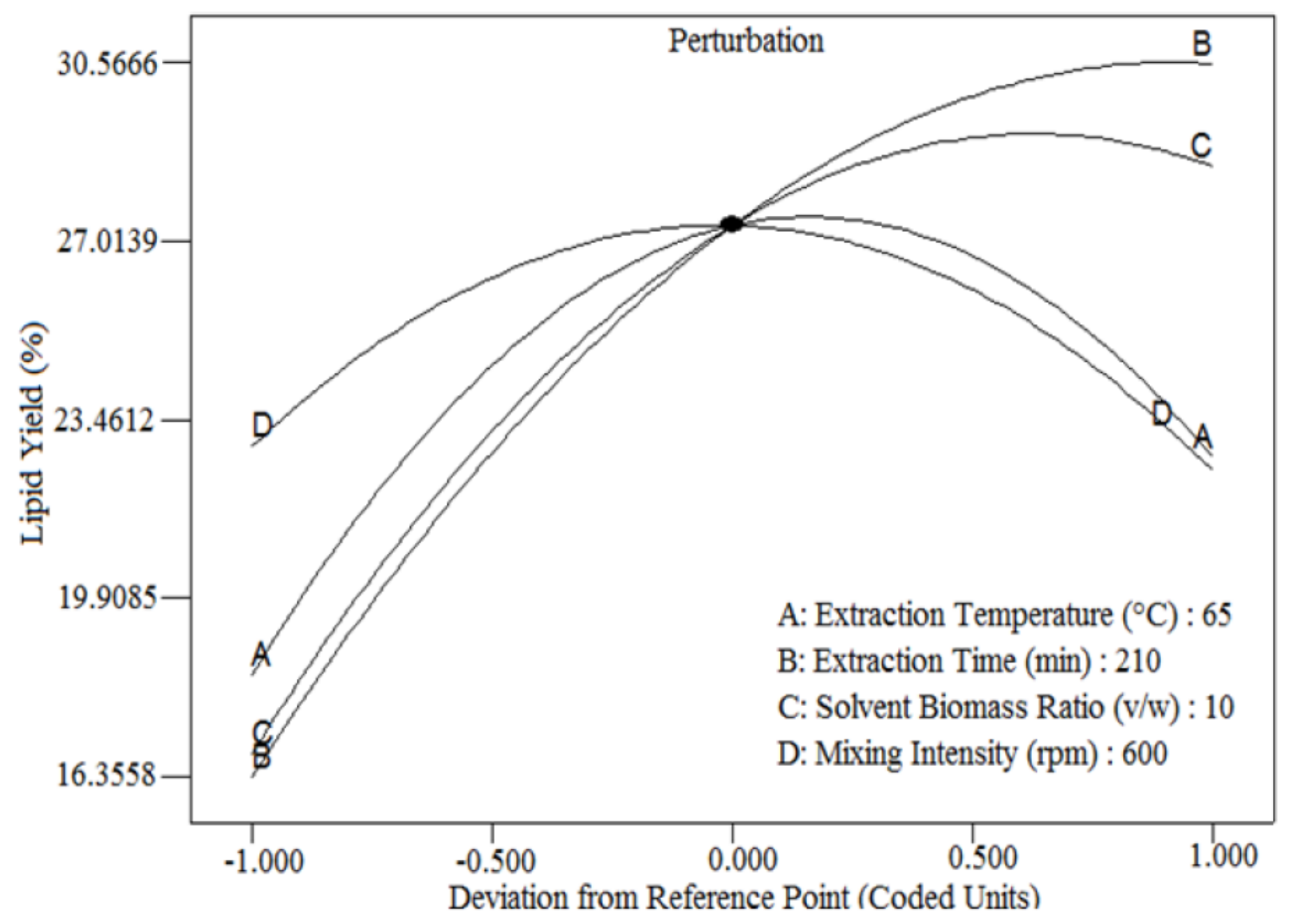

Figure 15

Perturbation chart to attain the influences of the lipid extraction process parameters on dry basis 

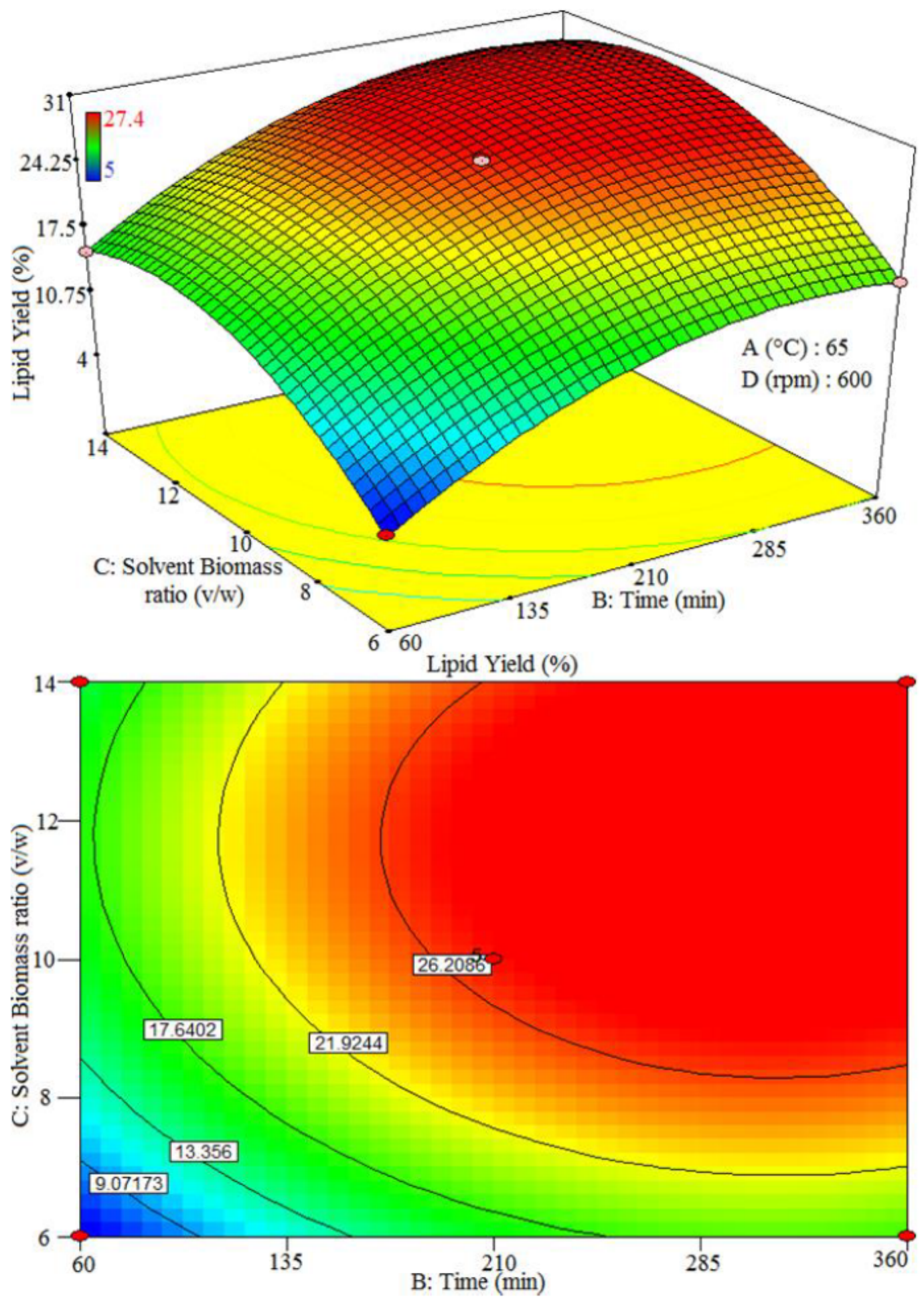

Figure 16

The 3D and contour plot of solvent biomass ratio and reaction time from the empirical model for maximizing the lipid yield from dry biomass 

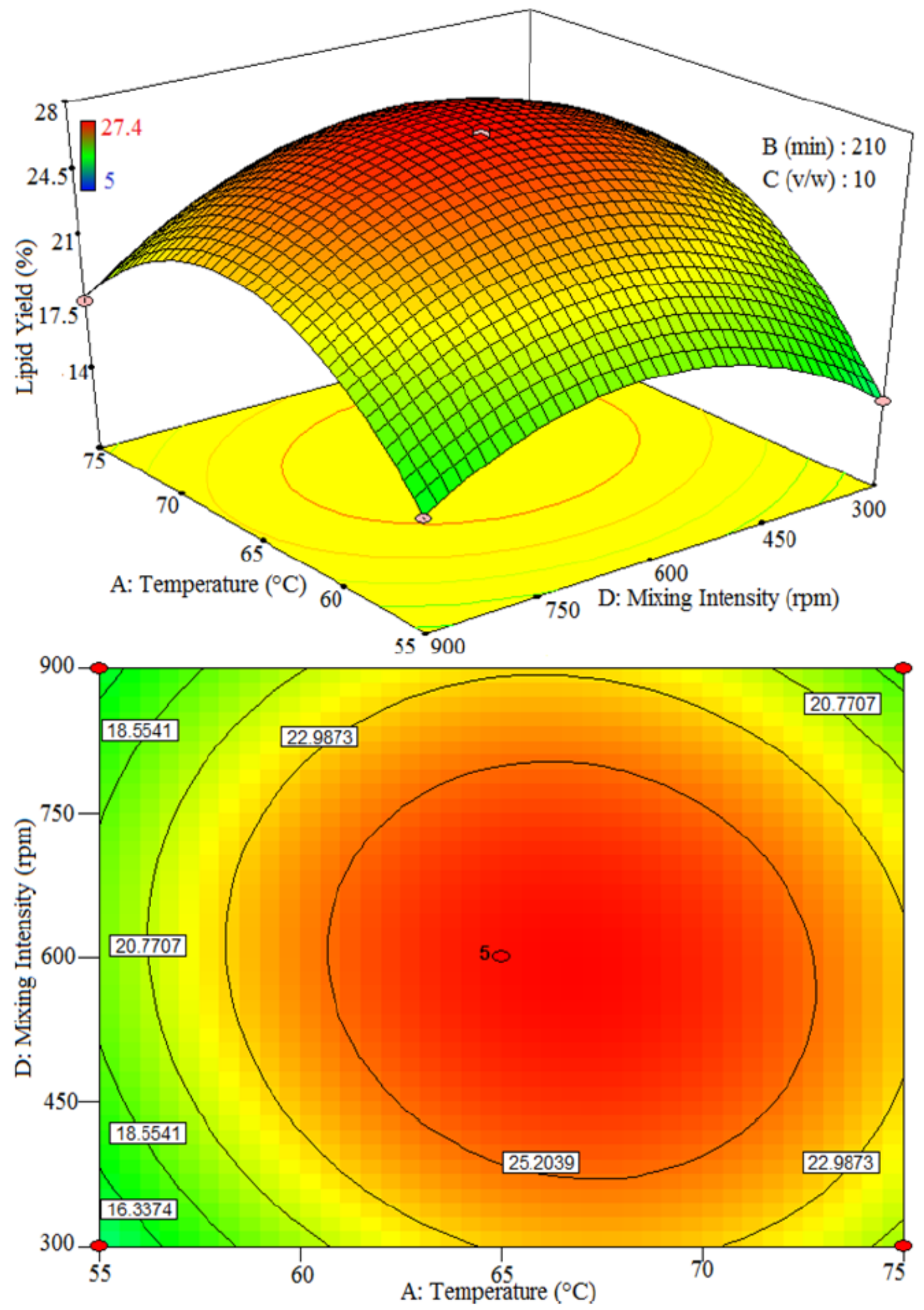

Figure 17

The 3D and contour plot of temperature and mixing intensity time from the empirical model for maximizing the lipid yield from dry biomass 


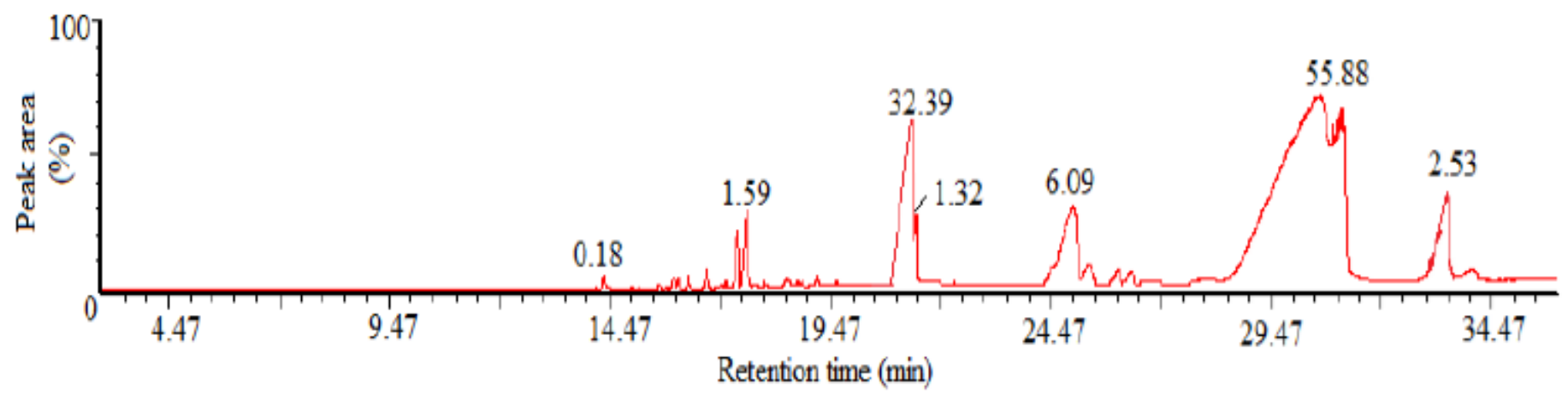

Figure 18

Graphical view of the fatty acid profile composition 